\title{
Nitration of Jharia basin coals, India: a study of structural modifications by XRD and FTIR techniques
}

\author{
Prabal Boral ${ }^{1} \cdot$ Atul K. Varma $^{2} \cdot$ Sudip Maity $^{1}$ (D)
}

Received: 16 August 2020/Revised: 11 January 2021/Accepted: 16 March 2021/Published online: 8 April 2021

(C) The Author(s) 2021

\begin{abstract}
Four coal samples from Jharia basin, India are treated with nitric acid in glacial acetic acid and aqueous media to find out the chemical, petrographic and spatial structure of the organic mass by X-ray diffraction (XRD) and Fourier Transform Infrared Spectroscopy (FTIR) techniques. X-ray parameters of coal like interlayer spacing $\left(d_{002}\right)$, crystallite size $\left(L_{\mathrm{c}}\right)$, aroamticity $\left(f_{\mathrm{a}}\right)$, average number of aromatic layers $\left(N_{\mathrm{c}}\right)$, and coal rank $\left(I_{26} / I_{20}\right)$ have been determined using profilefitting software. Considerable variation is observed in treated coals in comparison to the demineralized coals. The $d_{002}$ values of treated coals have increased in both the media showing increase in disordering of organic moieties. A linear relationship has been observed between $d_{002}$ values with the volatile matter of the coals. Similarly, the $d_{002}$ values show linear relationship with $\mathrm{C}_{\mathrm{dmf}}$ contents for demineralized as well as for the treated coals in both the media. The $L_{\mathrm{c}}$ and $N_{\mathrm{c}}$ values have decreased in treated coals corresponding to demineralized coals. The present study shows that nitration in both the media is capable of removing the aliphatic side chains from the coals and aromaticity $\left(f_{\mathrm{a}}\right)$ increases with increase in rank and shows a linear relationship with the vitrinite reflectance. The corresponding $I_{26} / I_{20}$ values are least for treated coals in glacial acetic acid medium followed by raw and then to treated coals in aqueous medium. FTIR studies show that coal arenes of the raw coals are converted into nitro-arenes in structurally modified coals (SMCs) in both the media, the corresponding bands at $1550-1490$ and $1355-1315 \mathrm{~cm}^{-1}$ respectively. FTIR study confirms that nitration is the predominant phenomenon, though, oxidation and nitration phenomena takes place simultaneously during treatment with nitric acid to form SMCs. In comparison to raw coals, the SMCs show higher aromaticity and may be easily converted to coal derived products like activated carbon and specialty carbon materials.
\end{abstract}

Keywords Coal $\cdot$ Micro-structure $\cdot$ Nitration $\cdot$ XRD $\cdot$ FTIR

\section{Introduction}

Coal has manifold uses, as for instance, solid fuel, gives coke for metallurgical use, coal chemicals and many more. Several chemical products can be produced from the coal and/or its by-products. Coal has several advantages when

Sudip Maity

sudip_maity@yahoo.com

1 CSIR-Central Institute of Mining and Fuel Research, PO: FRI, Dhanbad 828108, India

2 Department of Applied Geology, Indian Institute of Technology (ISM), Dhanbad, 826004, India considered as a feedstock for aromatic chemicals and carbon based materials. It can be used in producing activated carbon (AC), carbon molecular sieve (CMS), specialty carbon materials (viz.: fullerene, artificial graphite, artificial diamond), composites of coal with other polymers, humic acid preparations etc.

Hence, the study molecular structure of coals and their structurally modified counter parts are very much essential to understand their basic nature and for suitability towards more meaningful industrial utilization. Coal is essentially a very heterogeneous and complex material and many models have been proposed to understand the molecular structure of it and their structurally modified counterparts 
(Domazetis and James 2006; Mathews and Chaffee 2012; Li et al. 2015; Yan et al. 2020). Earlier, Hirsch (1954) carried out X-ray diffraction studies of low rank coals and anthracite. He found that the low rank coals up to carbon content $85 \%$ have "open structure". Many studies like Transmission Electron Microscopy (TEM), Scanning Electron Microscopy (SEM), XRD, FTIR, Raman Spectroscopy, X-ray Photoelectron Spectroscopy (XPS), Nuclear Magnetic Resonance (NMR) and High-resolution Transmission Electron Microscopy (HR-TEM), have been used for coal molecular structure determination (Solum et al. 1989; Dangyu et al. 2011; Baysal et al. 2016; Barbara et al. 2019; Jing et al. 2019).

The role of X-ray diffraction is very important in coal science. Powder diffraction technique can be used to study the different phases present in coal. To address the heterogeneity of coal, this technique is immensely important as it uses relatively large amount of the sample and collects most of the intensities scattered from the sample (Lu et al. 2001). Coal has an intermediate structure between graphite and amorphous carbon, so-called turbostratic structure or random layer lattice structure (Maity and Mukherjee 2006). It also contains significant amount of highly disordered material, amorphous carbon, which is responsible for the background intensity of the diffractograms. However, recent developments of computer techniques have enabled more accurate calculations and detailed analysis of XRD profiles. Wertz's group (Wertz 1998; Wertz and Bissell 1994, 1995; Wertz and Quin 2000) has made extensive studies of coals using XRD technique and quantitatively characterized both mineral matter and organic matrix of coals. XRD analysis is a fundamental method for evaluating carbon stacking structure. The degree of graphitization, the interlayer spacing $\left(d_{002}\right)$, and the crystallite size $\left(L_{\mathrm{c}}\right)$, aromaticity $\left(f_{\mathrm{a}}\right)$, average number of aromatic layers $\left(N_{\mathrm{c}}\right)$ and XRD rank parameter $\left(I_{26} / I_{20}\right)$ have been established as the parameters for evaluating structure of highly crystalline carbon materials (Boral et al. 2015).

FTIR spectroscopy exploits the fact that molecules absorb or transmit specific frequencies that are characteristic of their structure. For coal, it is generally studied in mid-infrared zone, approximately $4000-400 \mathrm{~cm}^{-1}$ wave number range. Infrared spectroscopy gives information on the vibrational and rotational modes of motion of a molecule and hence an important technique for identification and characterization of functional groups. The Infrared spectrum of an organic compound provides a unique fingerprint, which is readily distinguished from the transmission patterns of all other compounds. Fourier transform is used to process the data from interferometer instrument. Modern FTIR instrument uses a laser-light, powerful computer and advanced software. The software performs processing, manipulation, plotting, resolution enhancement, peak position, area measurement, library searching (Painter et al. 1978; Painter and Colemon 1979; Solomon et al. 1990; Tamarkina et al. 2002). Radial distribution function (RDF) obtained from Fourier Transformation of molecular scattering is used to examine the molecular level structuring of coal. Tamarkina et al. (2002) used FTIR to study modification of different rank coals in equimolar nitric acid and acetic anhydride mixture.

To study the structural variations, four samples have been collected from Jharia Basin of India. Jharia Basin coal is very important as it is the only caking/coking coal producing horizon of India. The coal bearing horizon of the basin is subdivided into two stratigraphic formations, viz., Barakar and Raniganj. The Barakar Formation coals are the only source of the prime coking coal of India, while the Raniganj measure coals are the high volatile medium coking coals. For all the coal seams, it is observed that their maturity gradually decrease from west towards east, in both the coal measures. Coals of the Barakar Formation are generally low in moisture $(0.5 \%-2.0 \%)$ and medium to low volatile caking coal. The coals of the Raniganj Formation contain slightly higher moisture and high volatile matter content than the coals of Barakar Formation. All the samples are demineralized with standard $\mathrm{HCl}+\mathrm{HF}$ treatment method to avoid the effect of mineral matter in instrumental analyses (Maity and Mukherjee 2006). Each of the demineralized coal samples has been modified with nitric acid treatment in glacial acetic acid and in aqueous medium (Maity and Choudhury 2008). Thus, twelve numbers of samples have been prepared in total for the present study.

\section{Experimental}

\subsection{Collection of sample}

Jharia basin forms a part of the Damodar valley basins which includes Jharia, Raniganj, Bokaro, Karanpura and Ramgarh coalfields. These coalfields are separated from each other by Precambrian rocks in the outcrops. Jharia Coalfield (JCF) is situated about $260 \mathrm{~km}$ northwest of Kolkata in the heart of Damodar valley mainly along the north of the Damodor River. The coalfield is bounded between latitude $\mathrm{N} 23^{\circ} 37^{\prime}-\mathrm{N} 23^{\circ} 52^{\prime}$ and longitudes E86 $06^{\prime}-\mathrm{E} 86^{\circ} 36^{\prime}$ and lies within the district of Dhanbad. This sickle shaped coal basin extends for about $38 \mathrm{~km}$ in an east-west direction and a maximum of $19 \mathrm{~km}$ in northsouth direction and covers an area of about $456 \mathrm{~km}^{2}$. Out of this area; Barakar formation occupies an area of $216 \mathrm{~km}^{2}$, Raniganj Formation $54 \mathrm{~km}^{2}$ and rest Barren Measures 180 $\mathrm{km}^{2}$ (Krishnan 1982). 
The general stratigraphic succession (Chandra 1992) of the area is that the basement of metamorphic rocks overlain by the Talchir Formation followed by the Barakar Formation, which is the main coal bearing horizon. Above it, comes the Barren Measures (devoid of coal), which is followed by the coal-bearing Raniganj Formation. The Raniganj Formation is the uppermost coal bearing Formation in the Jharia coalfield. The thickness of Barakar Formation is about $800-1250 \mathrm{~m}$ with about 25 coal horizons, out of which 18 are regionally persistent. The upper coal measures of Raniganj Formation is approximately $800 \mathrm{~m}$ thick and contains 12 coal horizons, of which 4 to 5 are persistent in nature. In both the formations, the persistent coal seams have been numbered from bottom.

The present study is carried out on coals from of Mohuda (MH), Gasalitand (GT), Salanpur (SL) and Shatabdi (ST) mines of Jharia Coalfield which forms a part of the Damodar Valley basin. The details of coal samples are shown in Table 1.

The coal samples are crushed to below $212 \mu$ (IS 436 Part 1/Sec 1 2001) for this study, while samples for petrographic analysis are prepared by controlled crushing with below $1 \mathrm{~mm}$ size (IS 9127 Part 2 2002). The Gross Calorific Value (GCV) is measured (Standard: ASTM D5865) by Automatic Bomb calorimeter (Model AC-350 isoperibol bomb calorimeter, Leco, USA). The ultimate analysis of coal involves determination of the elemental composition of coal and is expressed in terms of weight percentages of carbon $(\mathrm{C})$, hydrogen $(\mathrm{H})$, nitrogen $(\mathrm{N})$, sulphur (S), and oxygen (O). Percentages of elemental C, $\mathrm{H}, \mathrm{N}$ and $\mathrm{S}$ are determined analytically while $\mathrm{O}$ is obtained by difference from hundred. Information derived from ultimate analysis is used for selection of coal for various efficient utilization purposes. Carbon, hydrogen and nitrogen percentages of each of the air-dried samples are determined by the Leco (USA) make CHN-1000 analyzer (ASTM D5373 2016). Analysis of sulphur (Standard: ASTM D5016 2016) is done by Leco (USA) (Make SC132), which is a microprocessor-based instrument and it has a control console for each system and a measurement unit with a built-in-balance.

The maceral analyses and vitrinite reflectance of each sample have been carried out in micro-petrographic analysis of coal. The maceral analysis is carried as per standard (IS 9127 Part 3 2002) procedure. The IS 9127 Part 5 2004, is used for reflectance measurement. Reflected light polarized microscopes (Make: Leitz; Model: MPV Compact, Germany and Make: Leica, Model: DMRX P $\mathrm{HC}$, Germany) have been used to study the maceral composition and reflectance measurements of the samples.

\subsection{Demineralization of samples}

All the raw coal samples contain inorganic mineral matter. The intensity of the diffraction peaks of these inorganic minerals is much sharper and stronger than that of the broad humps of the organic matter present in coal. It is very difficult to obtain accurate crystalline peaks of organic matters in X-ray diffraction pattern of crystalline organic matters in presence of inorganic mineral matters. So, the mineral matters present in coal are removed by demineralizing the coal samples using standard $\mathrm{HCl}+\mathrm{HF}$ solution to alleviate this problem (Maity and Mukherjee 2006).

Each ten grams of air dried sample of $212 \mu$ (X 72 mesh) size is accurately weighed and transferred to a Teflon beaker. To this $60 \mathrm{~mL}$ of concentrated $\mathrm{HCl}$ of $36.5 \mathrm{wt} \%$ is added slowly keeping it in a water bath. The temperature of the water bath is kept at $60{ }^{\circ} \mathrm{C}$. The mixture is stirred vigorously by a Teflon rod for three hours. Then the coal is filtered and washed with hot distilled water to remove $\mathrm{HCl}$. The filtered HCl-treated coal is again treated with $60 \mathrm{~mL}$ concentrated HF solution of $48 \mathrm{wt} \%$ purity. The mixture is again kept in water bath of $60{ }^{\circ} \mathrm{C}$ and stirred for another three hours. Finally, the HF treated coal is filtered and washed with hot distilled water to remove HF from coal. Removal of acid from coal is confirmed by $\mathrm{pH}$ test of the samples. Then residual coal in the filter paper is dried in an air-oven for $5-6 \mathrm{~h}$ at $50{ }^{\circ} \mathrm{C}$. The Demineralization is confirmed by the weight loss of the coal samples to at least less than $2 \%$ effective mineral matter for the samples.

\subsection{Chemical modification procedures}

Structural modification is carried by oxidative pretreatment of coal. Two types of chemical treatments are carried out for each of the demineralized coal samples to make

Table 1 Details of the collected samples

\begin{tabular}{lllllll}
\hline $\begin{array}{l}\text { Sample } \\
\text { No. }\end{array}$ & SN & Seam & Mine & Formation & Basin & Age \\
\hline 1 & MH & R-III (Top) & Mohuda & Raniganj & Jharia & Late Permian \\
2 & GT & XII/XIII & Gasalitand & Barakar & Jharia & Early Permian \\
3 & SL & III & Salanpur & Barakar & Jharia & Early Permian \\
4 & ST & II & Shatabdi & Barakar & Jharia & Early Permian \\
\hline
\end{tabular}


structurally modified coals (SMCs). The demineralized coal samples are treated with concentrated nitric acid in different media viz. in glacial acetic acid and in aqueous media to form SMCs (Maity and Choudhury 2008).

$2 \mathrm{~g}$ of demineralized coal is weighed accurately and $10 \mathrm{~mL}$ of glacial acetic acid is mixed thoroughly in beaker. The mixture is kept in a water bath at a temperature of $15-20{ }^{\circ} \mathrm{C}$ by adding ice to the water bath. The temperature of the bath is monitored so as to maintain the desired temperature. To this mixture, $3 \mathrm{~mL}$ of concentrated nitric acid $\left(\mathrm{HNO}_{3}\right.$ at $\left.68 \mathrm{wt} \%\right)$ is added drop by drop and stirred thoroughly. This $3 \mathrm{~mL} \mathrm{HNO}_{3}$ was mixed to the mixture of coal and glacial acetic for at least half an hour duration and after that kept for $24 \mathrm{~h}$. After $24 \mathrm{~h}$, the mixture is diluted with $250 \mathrm{~mL} / \mathrm{g}$ distilled water and left for another $24 \mathrm{~h}$. The mixture is then filtered and washed with hot distilled water till neutralization ( $\mathrm{pH}$ value is approx. 7.0) is attained. Then the treated coal is dried in an air-oven at 50 ${ }^{\circ} \mathrm{C}$ for $5-6 \mathrm{~h}$ and kept in desiccators. After treatment of each sample the difference in weight is measured.

In the second treatment, two grams of demineralized coal is taken in a refluxing condenser. Pure nitrogen gas is purged through it before the treatment. Then $60 \mathrm{~mL}$ of $30 \%$ nitric acid is mixed to the coal. The coal acid mixture is heated at $105 \pm 5{ }^{\circ} \mathrm{C}$ and stirred well. The reaction continues for $8-10 \mathrm{~h}$ or till the end of any gas evolution from the coal-acid mixture. The residue left in the flask is filtered and washed with hot distilled water till any trace of nitric acid is removed and neutralization is confirmed by $\mathrm{pH}$ test. After each treatment, the sample is dried in an air-oven at $50{ }^{\circ} \mathrm{C}$ for $5-6 \mathrm{~h}$ and kept in desiccators and the difference in weight is calculated using the formula:

$\Delta \mathrm{wt} \%=\left(W_{\mathrm{f}}-W_{\mathrm{i}}\right) / W_{\mathrm{i}}$

where, $W_{\mathrm{f}}$ and $W_{\mathrm{i}}$ are the final and initial weight of the coal sample after and before treatment of coal respectively.

The demineralized coal samples are coded with suffix (D), nitric acid treated coals in glacial acetic acid medium with suffix (G) and aqueous nitric acid treated coals with (A). As for example the Mohuda demineralized coal $\left(\mathrm{MH}_{\mathrm{D}}\right)$, viz. $\left(\mathrm{MH}_{\mathrm{G}}\right)$ for Mohuda nitric acid treated coals in glacial acetic acid medium and $\left(\mathrm{MH}_{\mathrm{A}}\right)$ for aqueous nitric acid treated coals.

\subsection{X-ray diffraction analysis}

X-ray Diffraction (XRD) analysis is performed by a D-8 ADVANCE (Bruker AXS, Germany) X-ray Diffractometer. This is used to collect the X-ray intensities of the demineralized and treated coals in the $2 \theta$ range of $10^{\circ}-90^{\circ}$ with Bragg-Brentano geometry, using parallel beam $\mathrm{Cu} \mathrm{K}_{\alpha}$ $(40 \mathrm{kV}, 40 \mathrm{~mA})$ radiation. An X-ray amorphous sample holder is used for coal sample loading, and the scan is made in locked couple step scan mode $(0.02 \%$ step), with $2 \mathrm{~s}$ at each step.TOPAS 3.0 from Bruker AXS (2005), Germany is used for de-convolution of the diffractograms in the $2 \theta$ region of $10^{\circ}-35^{\circ}$. Two symmetrical Gaussian peaks are fitted for determination of $\pi$-band and $\gamma$-band to determine the $d_{002}$ and position of $\gamma$-band $\left(D_{\gamma}\right)$ respectively. XRD profile curve fitting of two Gaussian peaks for the Mohuda (MH) demineralized coal in the range of $10^{\circ}-35^{\circ}$ is shown in Fig. 1 as an example. The carbon-related peaks around $20^{\circ}-26^{\circ} \mathrm{can}$ be categorized into $\pi$ (002-band) and $\gamma$ band for aromatic and aliphatic chains respectively. The $\pi$ band due to aromatic ring stacking occurs near $26^{\circ}$, while $\gamma$-band around $20^{\circ}$, are believed to be derived from aliphatic chains. TOPAS 3.0 software is used for refinement of $\pi$-band and $\gamma$-band to determine the $d_{002}$, position of $\gamma$ band $\left(D_{\gamma}\right)$, average crystallite size $\left(L_{\mathrm{c}}\right)$, average number of aromatic layers $\left(N_{\mathrm{c}}\right)$, ratio of intensity of $\pi$-band and $\gamma$ band $\left(I_{26} / I_{20}\right)$ and aromaticity $\left(f_{\mathrm{a}}\right)$ (Maity and Mukherjee 2006; Boral et al. 2015). The software package uses the fundamental parameter approach (FPA) and is therefore capable of estimating the instrumental influence. The Double-Voigt approach in TOPAS is used with both calculated FPA and measured instrument functions. XRD analyses are carried out for all the demineralized coal samples and their corresponding SMCs formed by nitration in glacial acetic acid medium and aqueous medium.

\subsection{Fourier transform infra red spectroscopy}

Fourier transform infra red spectroscopy (FTIR) is extensively used for quantitative as well as for qualitative analysis in almost all fields of science (Painter et al. ; Painter and Colemon 1979; Solomon et al. 1990; Jing et al. 2019; Wu and Zhang 2019). Bruker (Germany) make 3000 Hyperion Microscope with Vertex 80 model FTIR-imaging system has been used to analyze the samples.

The FTIR spectra of all the samples are carried out in the range of spectral band of 4000 to $450 \mathrm{~cm}^{-1}$. For each sample analysis, thirty two scans are co added at a resolution of $2 \mathrm{~cm}^{-1}$. For spectral analysis, $\mathrm{KBr}$ matrix method is applied to prepare the samples. Sample and dry $\mathrm{KBr}$ in the ratio of 1:100 are ground and mixed in an agate mortar. Pellets of $13 \mathrm{~mm}$ diameter are prepared using $250 \mathrm{mg}$ of this mixture by pressing it in an evacuated die at 10 tonnes pressure in a hydraulic press. Origin 6.1 software is used to de-convolute FTIR spectrum and multi-peak Gaussian probability density function fit obtained for each functional group. Multi-peak Gaussian probability curve fit of FTIR analysis of Mohuda (MH) coal is shown as an example in Fig. 2. The area under each functional group is calculated for demineralized as well as treated coals in glacial acetic acid and in aqueous nitric acid with the help software. 


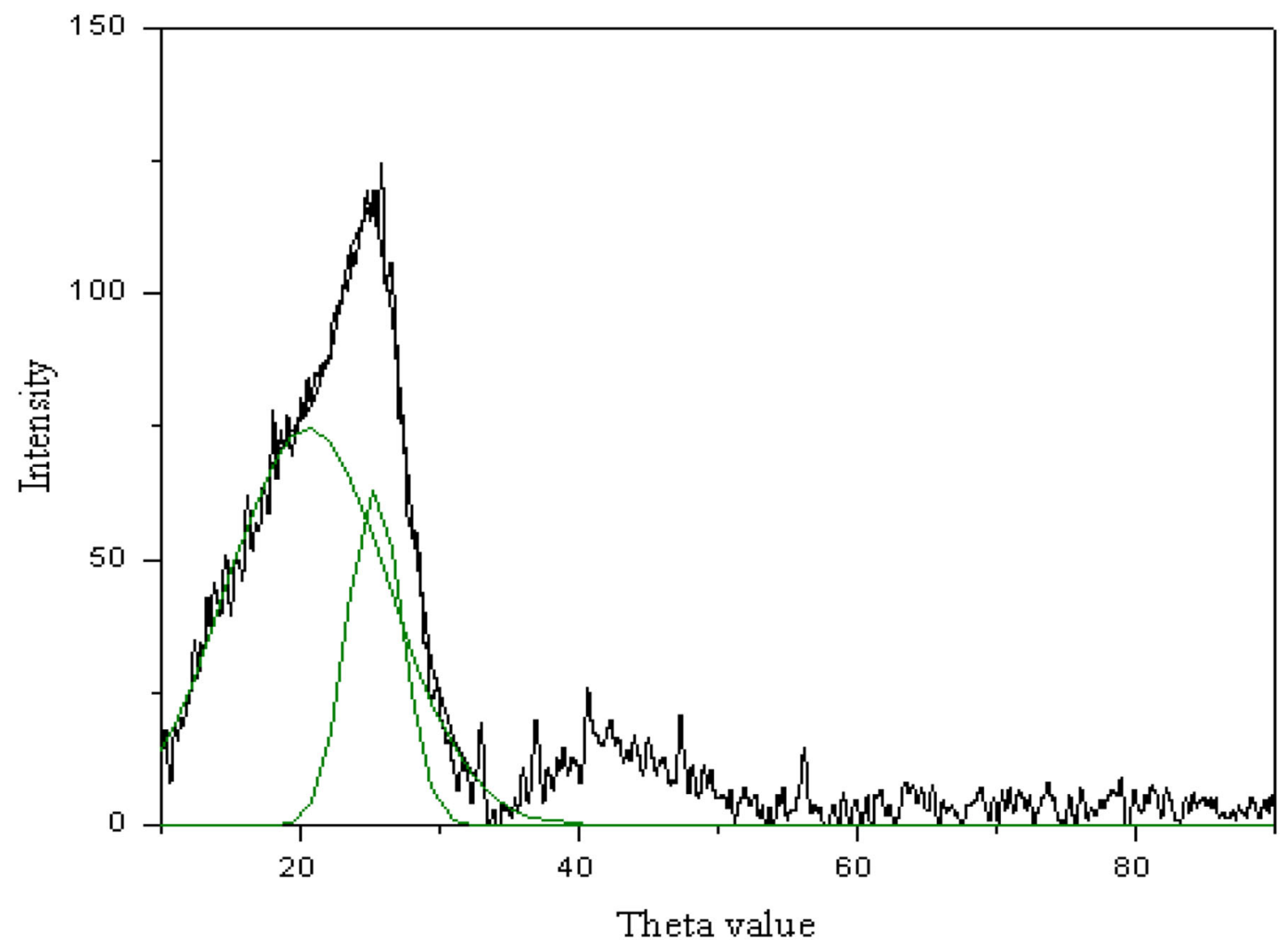

Fig. 1 XRD profile curve fitting of two Gaussian peaks for the Mohuda $(\mathrm{MH})$ demineralized coal in the range of $10^{\circ}-35^{\circ}$

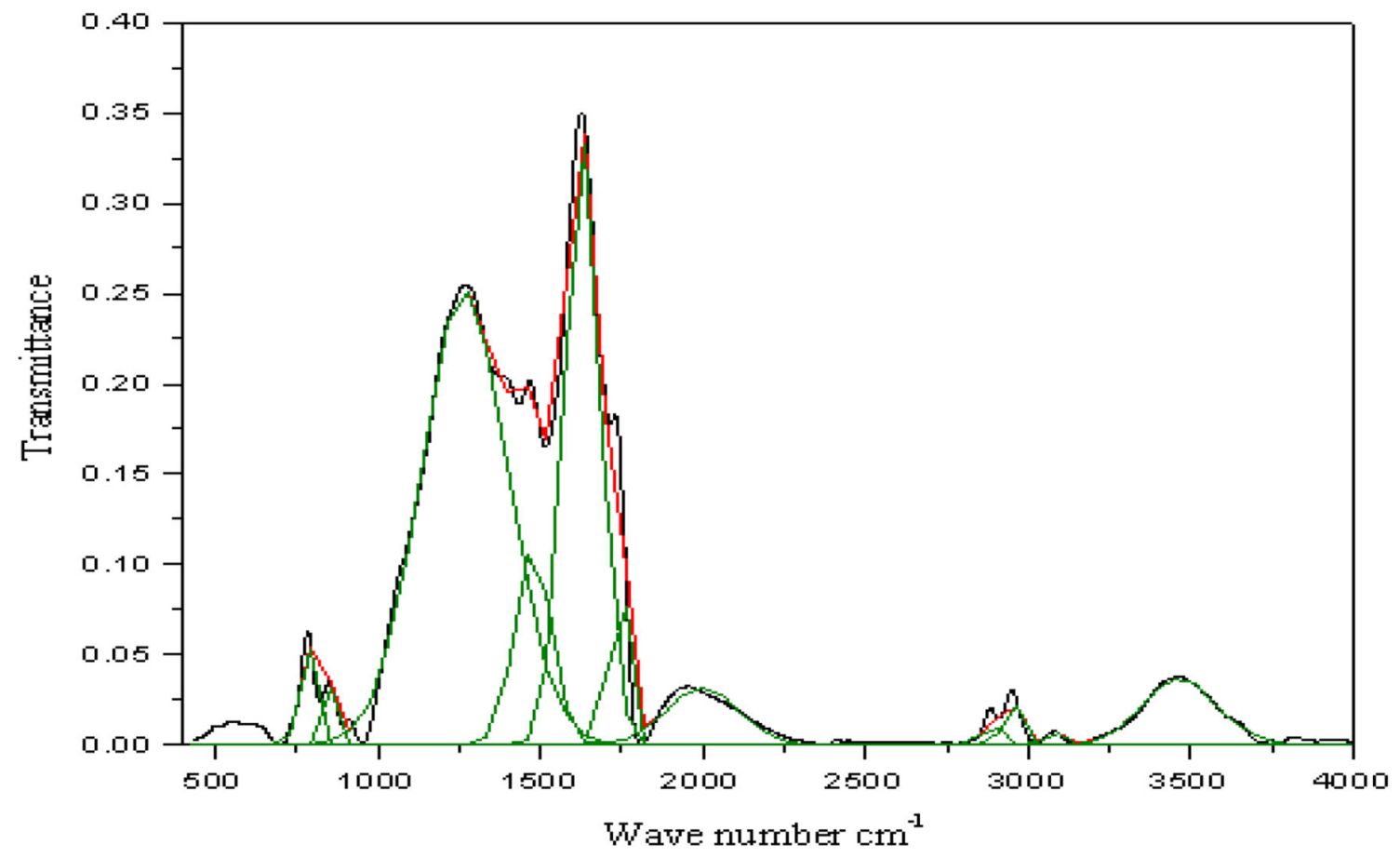

Fig. 2 Multi-peak Gaussian probability curve fit of FTIR analysis of Mohuda (MH) 


\section{Results and discussions}

\subsection{Coal properties}

Proximate, Ultimate, Gross Calorific Value (GCV) and Petrographic analyses data of the raw coals are shown in Table 2. The dry mineral free volatile matter $\left(\mathrm{VM}_{\mathrm{dmf}}\right)$ contents show that (MH, GT and SL) belong to medium volatile coals $(25.8 \%-30.3 \%)$, while ST having $21.0 \mathrm{wt} \%$ VM yield belongs to low volatile coal. Fixed carbon $\left(\mathrm{FC}_{\mathrm{dmf}}\right)$ ranged between $69.7 \%$ and $79.0 \%$ and $\mathrm{GCV}_{\mathrm{dmf}}$ of the samples vary between 8450 and $8640 \mathrm{kcal} / \mathrm{kg}$ and are of high maturity. The $\mathrm{C}_{\mathrm{dmf}}$ content of studied coals varies between $86.46 \%$ and $90.88 \%$ and also indicates that the samples are matured bituminous coals. The dry mineral free hydrogen, nitrogen and oxygen ranges from 5.19\%$5.87 \%, 1.71 \%-1.98 \%$ and $1.82 \%-5.30 \%$ respectively, typical of Indian bituminous coal. The sulphur content of Indian Gondwana coals are generally less than $1 \%$ and it ranges between $0.47 \%$ and $0.64 \%$ in the present study (Table 2).
Petrographic analyses of coals reveal vitrinite reflec-

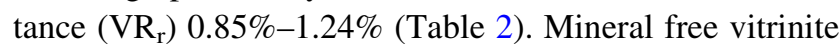
content varies between $70.8 \%$ and $37.9 \%$, liptinite $0.4 \%$ and $4.6 \%$ and inertinite between $37.9 \%$ and $70.8 \%$. The volatile matter yield is the combined effect of maceral contents of the coals (Borrego et al. 2000; Guerrero et al., 2013). It is considered to be the highest for liptinite maceral followed by vitrinite and inertinite. It can be seen from the analyses that liptinite content of the samples are not very significant. Hence, a plot between vitrinite content and volatile matter is drawn (Fig. 3) which shows a straight line curve with $R^{2}$ value of 0.87 . This is obvious as with increase of temperature, maturity increases (increase in reflectance) resulting devolatilization and decrease in VM (Alonso et al. 2001) and hydrogen content also decreases with decrease in VM (Table 2).

\subsection{Changes in weight on nitration}

The change in weight due to treatment is shown in Table 3. It is observed that in glacial acetic acid medium, the

Table 2 Proximate, ultimate, gross calorific value and petrographic analyses of coals

\begin{tabular}{|c|c|c|c|c|c|c|c|c|c|c|c|c|}
\hline SN & $\begin{array}{l}\mathrm{VM}_{\mathrm{dmf}} \\
(\mathrm{wt} \%)\end{array}$ & $\begin{array}{l}\mathrm{FC}_{\mathrm{dmf}} \\
(\mathrm{wt} \%)\end{array}$ & $\begin{array}{l}\mathrm{GCV}_{\mathrm{dmf}}(\mathrm{kcal} / \\
\mathrm{kg})\end{array}$ & $\begin{array}{l}\mathrm{C}_{\mathrm{dmf}} \\
(\mathrm{wt} \%)\end{array}$ & $\begin{array}{l}\mathrm{H}_{\mathrm{dmf}} \\
(\mathrm{wt} \%)\end{array}$ & $\begin{array}{l}\mathrm{S}_{\mathrm{dmf}} \\
(\mathrm{wt} \%)\end{array}$ & $\begin{array}{l}\mathrm{N}_{\mathrm{dmf}} \\
(\mathrm{wt} \%)\end{array}$ & $\begin{array}{l}\mathrm{O}_{\mathrm{dmf}} \\
(\mathrm{wt} \%)\end{array}$ & $\begin{array}{l}V_{\text {mmf }} \\
\text { Volu }\end{array}$ & $\begin{array}{l}\mathrm{L}_{\mathrm{mmf}} \\
\mathrm{e}(\%)\end{array}$ & $\mathrm{I}_{\mathrm{mmf}}$ & $\begin{array}{l}\mathrm{VR}_{\mathrm{r}} \\
(\%)\end{array}$ \\
\hline MH & 30.3 & 69.7 & 8550 & 86.46 & 5.87 & 0.47 & 1.91 & 5.30 & 70.8 & 4.6 & 24.6 & 0.85 \\
\hline GT & 28.1 & 71.9 & 8630 & 87.37 & 5.44 & 0.65 & 1.71 & 4.82 & 63.7 & 0.4 & 35.9 & 1.05 \\
\hline SL & 25.8 & 74.2 & 8640 & 89.02 & 5.23 & 0.80 & 1.98 & 2.97 & 43.9 & 0.9 & 55.2 & 1.17 \\
\hline ST & 21.0 & 79.0 & 8450 & 90.88 & 5.19 & 0.64 & 1.82 & 1.82 & 37.9 & 2.9 & 59.2 & 1.24 \\
\hline
\end{tabular}

Notes: SN: sample name, VM: volatile matter yield, FC: fixed carbon, GCV: gross calorific value, C: carbon, H: hydrogen, S: sulphur, N: nitrogen, $\mathrm{O}$ : oxygen, dmf: dry mineral free, $\mathrm{V}$ : vitrinite, $\mathrm{L}$ : liptinite, I: inertinite, $\mathrm{MM}$ : mineral matter, $\mathrm{VR}_{\mathrm{r}}$ : mean random reflectance of vitrinite, ${ }_{\text {mmf }}$ : mineral matter free basis

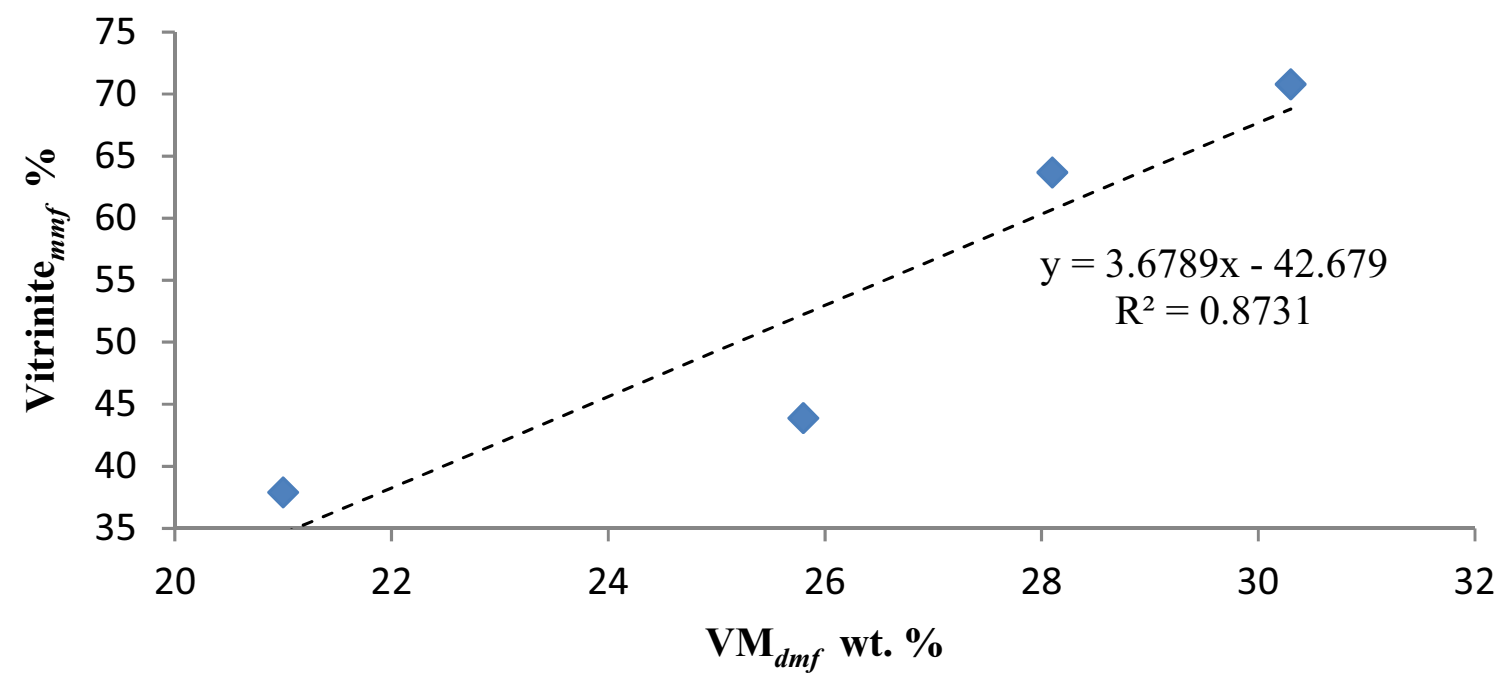

Fig. 3 Relation of Vitrinite content with respect to Volatile Matter 
Table 3 Change in weight due to nitration

\begin{tabular}{llll}
\hline Sample No. & $\mathrm{SN}$ & $\begin{array}{l}\text { G. Ac. Acid }+\mathrm{HNO}_{3} \\
\text { Change in wt\% }\end{array}$ & $\begin{array}{l}\text { Aq. } \mathrm{HNO}_{3} \\
\text { Change in wt\% }\end{array}$ \\
\hline 1 & $\mathrm{MH}_{\mathrm{D}}$ & 19.08 & -10.39 \\
2 & $\mathrm{GT}_{\mathrm{D}}$ & 19.78 & 13.59 \\
3 & $\mathrm{SL}_{\mathrm{D}}$ & 15.29 & 15.00 \\
4 & $\mathrm{ST}_{\mathrm{D}}$ & 16.37 & 15.44 \\
\hline
\end{tabular}

Table 4 XRD analysis of demineralized and nitric acid treated coals

\begin{tabular}{lllllll}
\hline Sample No. & $d_{002}(\AA)$ & $L_{\mathrm{c}}(\AA)$ & $f_{\mathrm{a}}$ & $N_{\mathrm{c}}$ & $I_{26} / I_{20}$ & $D \gamma(\AA)$ \\
\hline $\mathrm{MH}_{\mathrm{D}}$ & 3.484 & 23 & 0.44 & 6.60 & 1.82 & 4.30 \\
$\mathrm{MH}_{\mathrm{G}}$ & 3.487 & 21 & 0.47 & 6.02 & 1.56 & 4.14 \\
$\mathrm{MH}_{\mathrm{A}}$ & 3.486 & 21 & 0.68 & 6.02 & 2.90 & 4.20 \\
$\mathrm{GT}_{\mathrm{D}}$ & 3.471 & 25 & 0.50 & 7.20 & 1.97 & 4.27 \\
$\mathrm{GT}_{\mathrm{G}}$ & 3.480 & 21 & 0.51 & 6.03 & 1.75 & 4.26 \\
$\mathrm{GT}_{\mathrm{A}}$ & 3.473 & 22 & 0.71 & 6.33 & 2.95 & 4.31 \\
$\mathrm{SL}_{\mathrm{D}}$ & 3.454 & 25 & 0.52 & 7.24 & 2.20 & 4.19 \\
$\mathrm{SL}_{\mathrm{G}}$ & 3.466 & 23 & 0.53 & 6.64 & 1.85 & 4.18 \\
$\mathrm{SL}_{\mathrm{A}}$ & 3.460 & 23 & 0.72 & 6.65 & 3.09 & 4.12 \\
$\mathrm{ST}_{\mathrm{D}}$ & 3.451 & 25 & 0.53 & 7.24 & 2.54 & 4.03 \\
$\mathrm{ST}_{\mathrm{G}}$ & 3.462 & 24 & 0.54 & 6.93 & 2.21 & 4.28 \\
$\mathrm{ST}_{\mathrm{A}}$ & 3.452 & 24 & 0.73 & 6.95 & 3.38 & 4.07 \\
\hline
\end{tabular}

weights of the samples have increased. Since, the medium is non-aqueous; less oxidation has taken place in the coal moieties resulting into gain in weight of all the studied samples. MH coal shows reduction in weight (shown with negative sign in the Table 3) in the case of nitration in aqueous medium. Rest of the samples treated with aqueous nitric acid has gained weight. $\mathrm{MH}$ being low in rank $\left(\mathrm{VR}_{\mathrm{r}}\right.$ $=0.85 \%$ ) in comparison to the other three samples, oxidation is predominant phenomenon with simultaneous nitration in aqueous medium which has removed the aliphatic side chains resulting into decrease in weight of the said samples. Nitration is the predominant phenomena with simultaneous oxidation in stronger aqueous medium for higher rank coals.

\subsection{X-ray Diffraction studies}

The results of X-ray scattering analysis are shown in Table 4 . The $d_{002}$ values of demineralized coals are plotted against $\mathrm{VM}_{\mathrm{dmf}}(\mathrm{wt} \%)$ (Table 2) and shown in Fig. 4. It is observed that $d_{002}$ decreases with decrease in $\mathrm{VM}_{\mathrm{dmf}}$ and maintains a linear relationship with coefficient of determination, $R^{2}=0.82$. It is known that $d_{002}$ decreases with increase in maturity, vis-à-vis decrease in volatile matter yield of the coal (Lu et al. 2001).

It is found that the corresponding inter layer spacing of $\pi$-band $\left(d_{002}\right)$ are the least for raw coals followed by $d_{002}$ values of treated coals in aqueous medium and then to glacial acetic acid medium (Table 4). The $d_{002}$ values of demineralized coals as well as treated coals are plotted against dry mineral free carbon of coal samples $\left(\mathrm{C}_{\mathrm{dmf}}\right)$ which is shown in Fig. 5a-c and it is observed that $d_{002}$ value decreases with the increase of $\mathrm{C}_{\mathrm{dmf}}$. A similar relationship was found between $d_{002}$ and elemental carbon (Maity and Mukherjee 2006; Sonibare et al. 2010, Manoj and Kunjonama 2012) for demineralized coals where a linear relationship between $d_{002}$ and elemental $\mathrm{C}_{\mathrm{dmf}}$ is established fact. The nature of the graphs is similar for the demineralized as well as treated coals. An inverse relationship is found between $\mathrm{C}_{\mathrm{dmf}}$ and $d_{002}$ (D), with increase in $\mathrm{C}_{\mathrm{dmf}}$ content $d_{002}$ decreases with $R^{2}=0.88$ (Fig. 5a). Similar trend is also observed for the chemically modified coals having $R^{2}=0.93$ and $R^{2}=0.94$ for $d_{002}(\mathrm{G})$ and $d_{002}$ (A) respectively (Fig. 5b, c).

It is found that the corresponding $d_{002}$ values of coals treated with nitric acid in glacial acetic acid and aqueous media are increased. Aqueous medium being stronger in the present studied mediums might have dissolved the more aliphatic content of coal resulting in relative increase

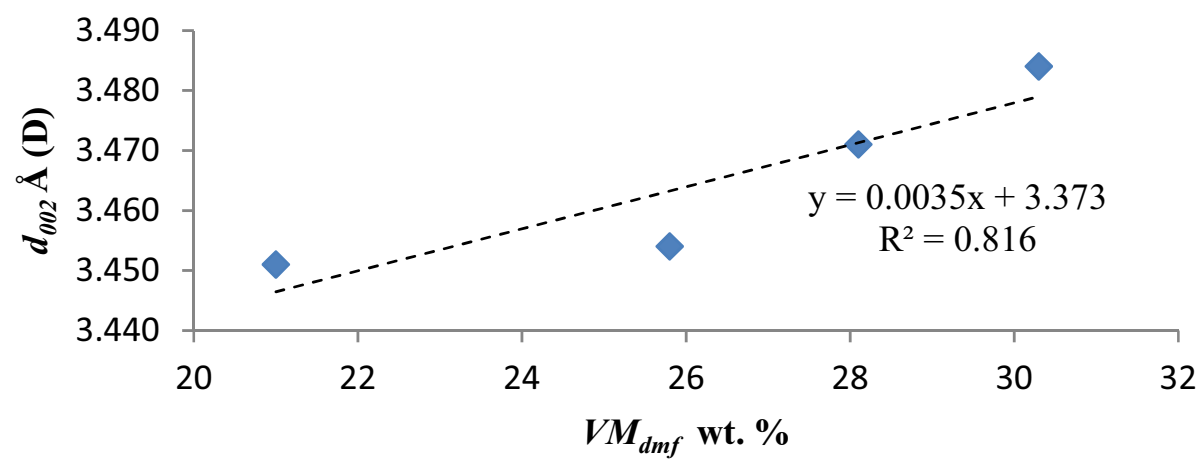

Fig. 4 Relation of $d_{002}$ with respect to Volatile Matter 


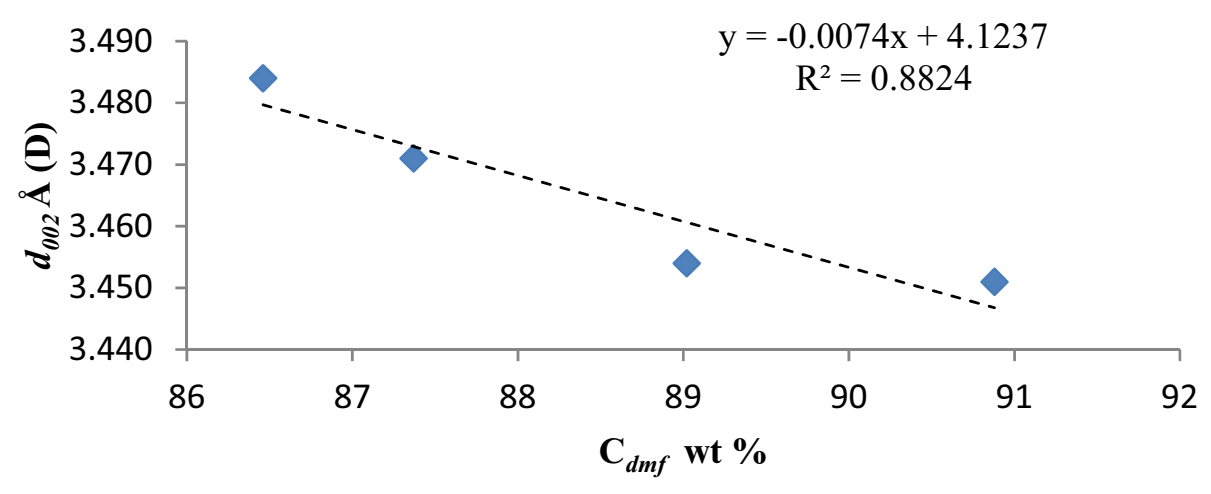

(a)

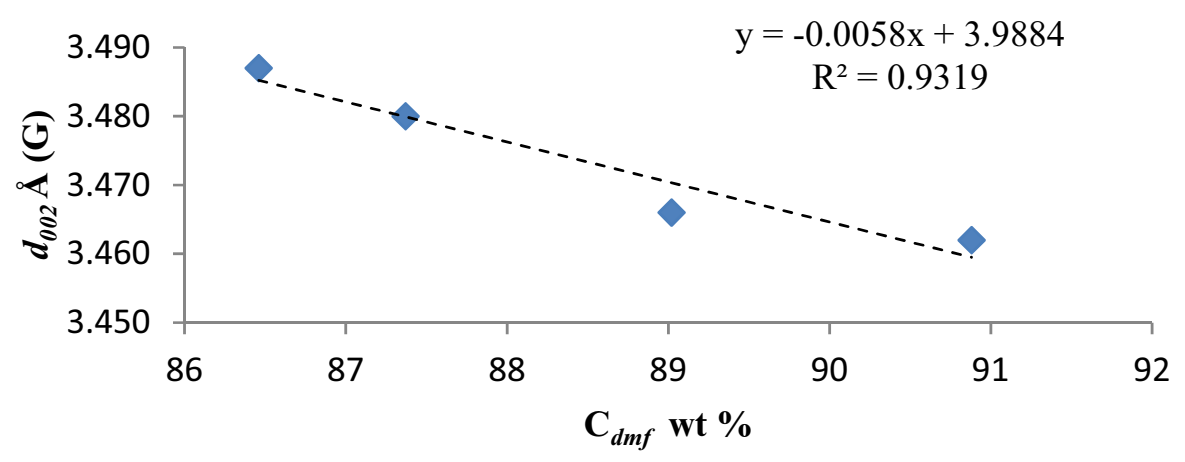

(b)

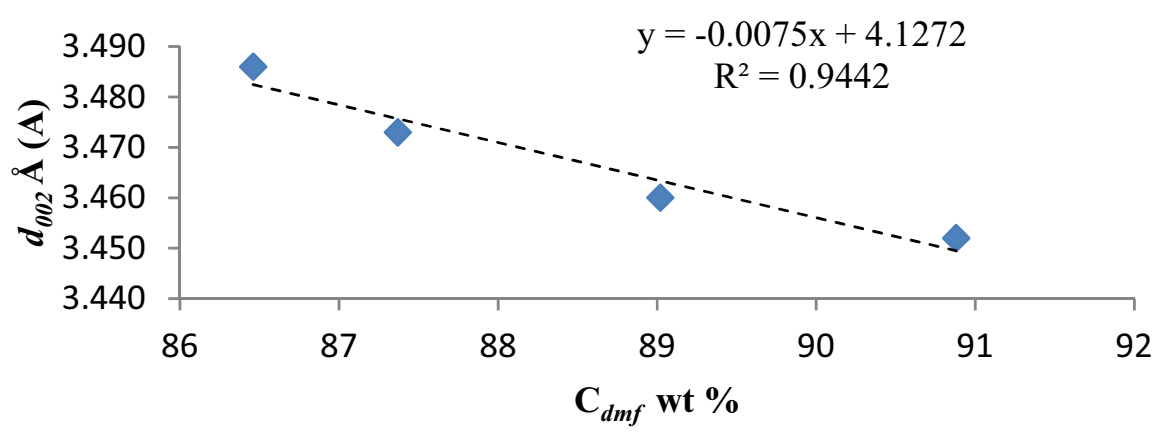

(c)

Fig. 5 Relation of $d_{002}$ with respect to $\mathrm{C}_{\mathrm{dmf}}$. a demineralized [( $\left.d_{002}(\mathrm{D})\right]$, b nitration in glacial acetic acid medium $\left[\left(d_{002}(\mathrm{G})\right]\right.$, $\mathbf{c}$ nitration in aqueous medium $\left[\left(d_{002}(\mathrm{~A})\right]\right.$ coals respectively

of aromatic moieties which lead to decrease in inter layer spacing $\left(d_{002}\right)$ in comparison to nitration in glacial acetic acid medium.

The results of mean crystallite size $\left(L_{\mathrm{c}}\right)$ of demineralized coals and their SMCs formed due to nitration in glacial acetic acid medium and in aqueous medium are shown in Table 4 . The $L_{\mathrm{c}}$ values of demineralized coals increase with increase in carbon content and vitrinite reflectance indicating crystallite sizes increase with increase in rank of the coals (Tables 2 and 4). Due to nitration, the disordering of molecular structure has taken place leading to decrease in mean crystallite size $\left(L_{\mathrm{c}}\right)$ of SMCs in comparison to the demineralized coals. Similar studies have been carried out by several other workers (Sonibare et al. 2010; Manoj and Kunjonama 2012) and corroborates with the present study.

The variation of aromaticity $\left(f_{\mathrm{a}}\right)$ of demineralized as well as nitric acid treated coal in glacial acetic acid medium and aqueous medium are shown in Table 4. It is found 


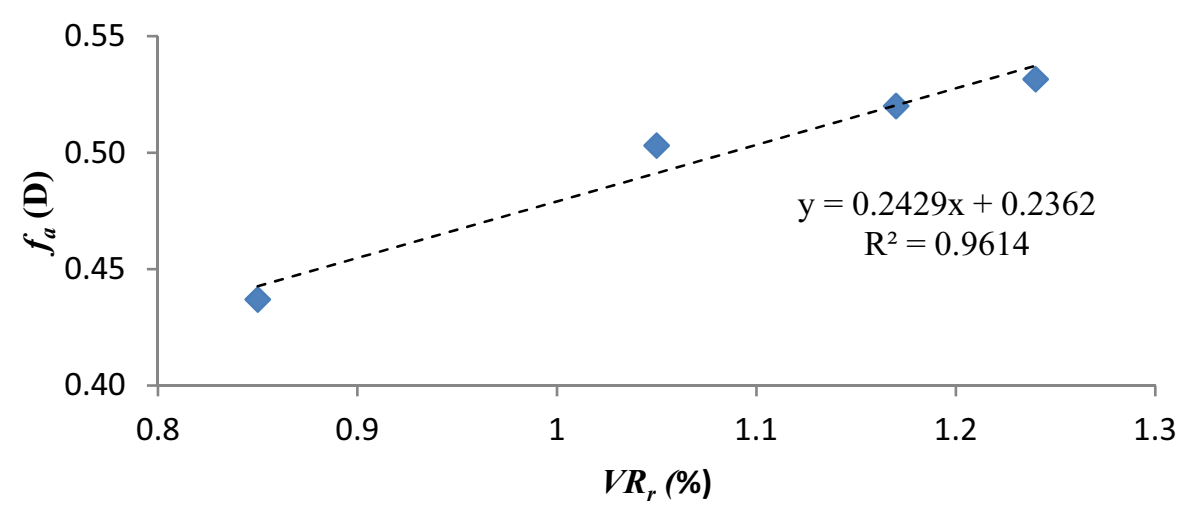

(a)

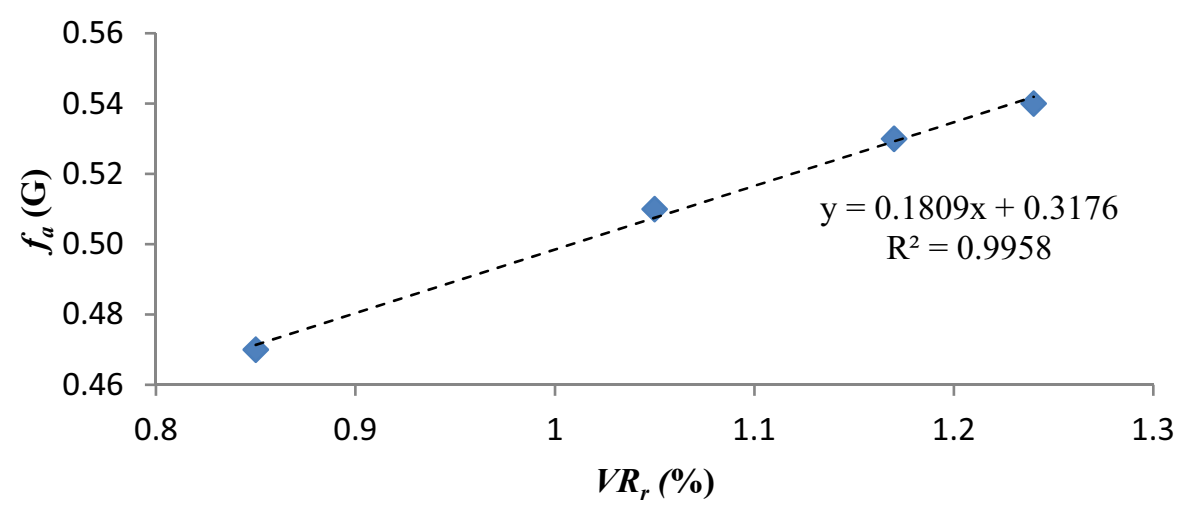

(b)

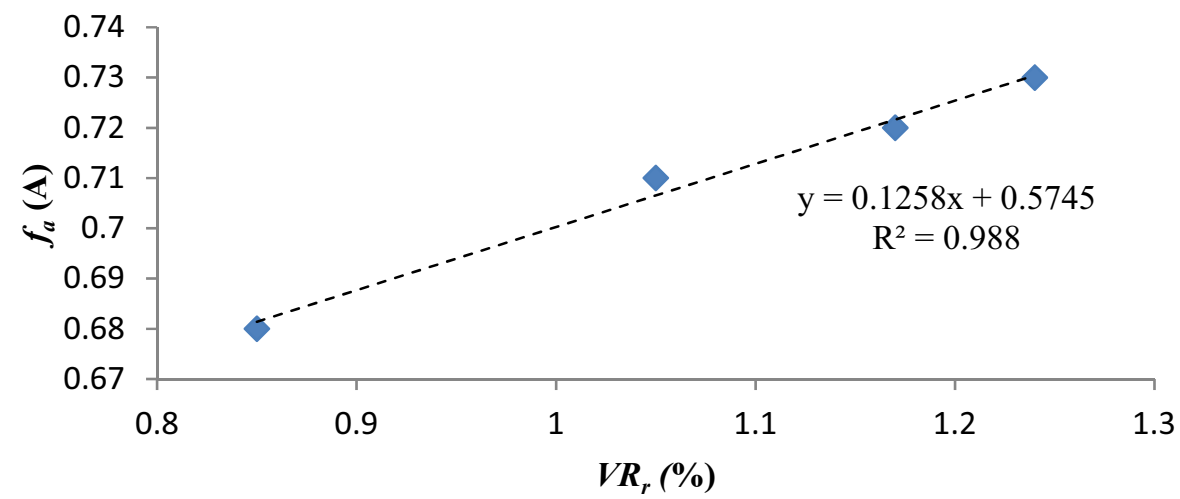

(c)

Fig. 6 Relation of $f_{\mathrm{a}}$ with respect to $\mathrm{VR}_{r} \%$. a demineralized $\left[\left(f_{\mathrm{a}}(\mathrm{D})\right]\right.$, b nitration in glacial acetic acid medium $\left[\left(f_{\mathrm{a}}(\mathrm{G})\right]\right.$ and $\mathbf{c}$ nitration in aqueous medium $\left[\left(f_{a}(\mathrm{~A})\right]\right.$ coals respectively

that corresponding $f_{\mathrm{a}}$ values are least for demineralized coals followed by treated coals in glacial acetic acid medium and then to aqueous medium. The increase in aromaticity in aqueous nitric acid treated coals is much more than that of nitration in glacial acetic acid medium. This suggests that aqueous medium is stronger than that of glacial acetic acid medium and is capable of removing more aliphatic contents resulting in more increase in aromaticity. The change in weight in both the media also indicates towards a similar conclusion (Table 3). The aliphatic contents are easily removed by aqueous nitric acid resulting into decrease in weight for $\mathrm{MH}$ coal and for relatively higher rank coals also the increase in weight is less in comparison to nitric acid treated coals in glacial acetic acid medium. 


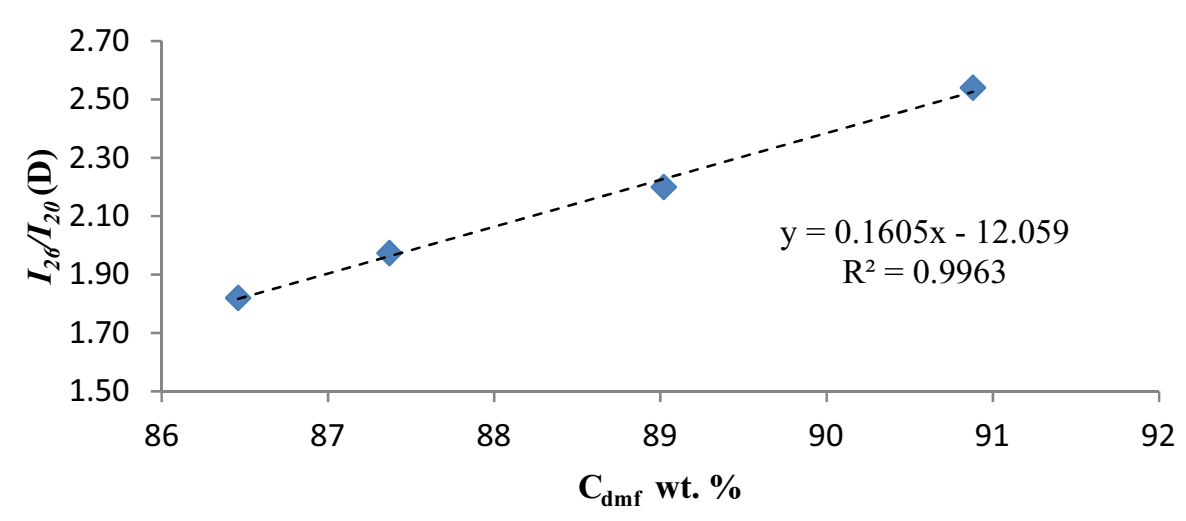

(a)

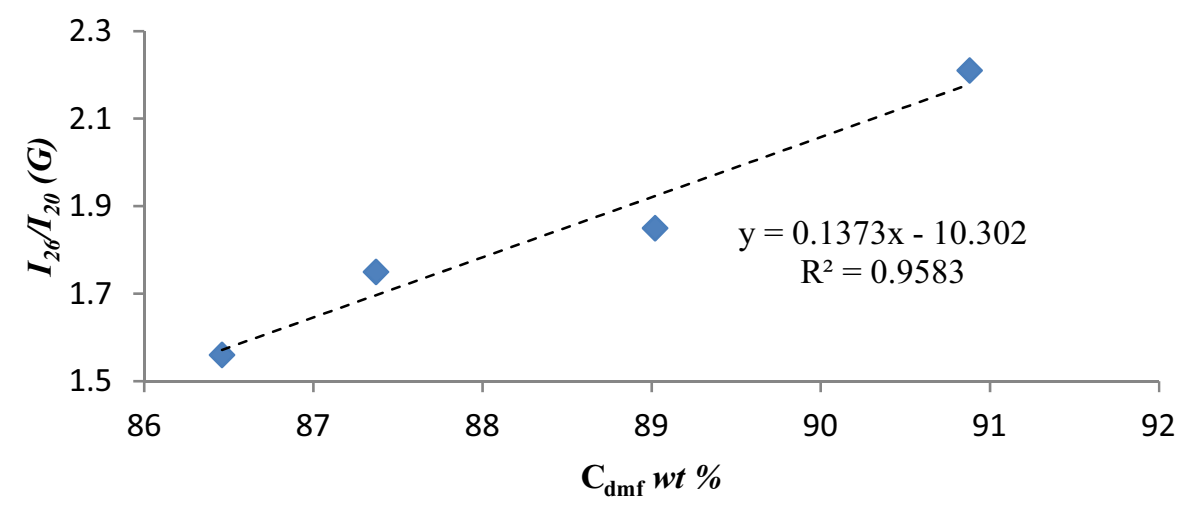

(b)

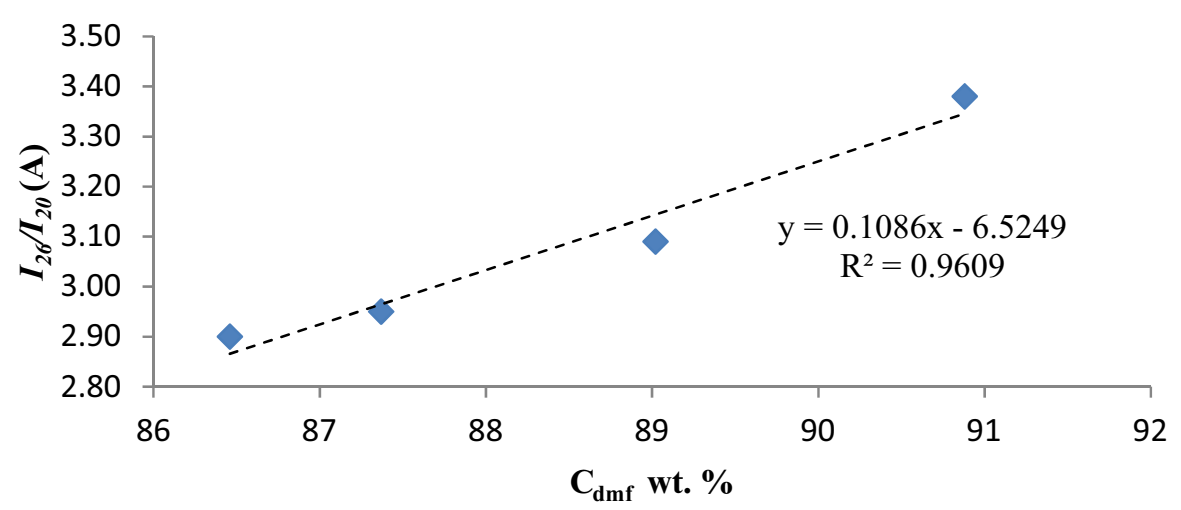

(c)

Fig. 7 a-c Relation of $I_{26} / I_{20}$ with respect to $C_{\text {dmf }}$ a demineralized $\left[\left(I_{26} / I_{20}(\mathrm{D})\right]\right.$, b nitration in glacial acetic acid medium $\left[\left(I_{26} / I_{20}(G)\right]\right.$ and c nitration in aqueous medium $\left[\left(I_{26} / I_{20}(\mathrm{~A})\right]\right.$ coals respectively

The vitrinite reflectance $\left(\mathrm{VR}_{r}\right)$ is also plotted against $f_{\mathrm{a}}$ and shown in Fig. 6. It shows an almost straight line relationship with coefficient of determination of $R^{2}=$ 0.9614 for demineralized coals, $R^{2}=0.9958$ for treated coals in glacial acetic acid and $R^{2}=0.998$ for coals with nitration in aqueous medium. It is to mention here that vitrinite reflectance is a very good indicator of rank and suggests that the aromaticity is more dependent on rank of the coals. The significant finding of this study is that nitration in the aromatic structure of coals is the predominant phenomenon with simultaneous oxy-destruction of aliphatic side chains resulting increase in the aromaticity. It also shows that aqueous medium being stronger between two media used for formation of SMCs of present study is capable of removing more aliphatic components resulting into more aromaticity of the samples in the said medium.

The average number of aromatic layers $\left(N_{\mathrm{c}}\right)$ for demineralized and the treated coals are shown in Table 4. It can 


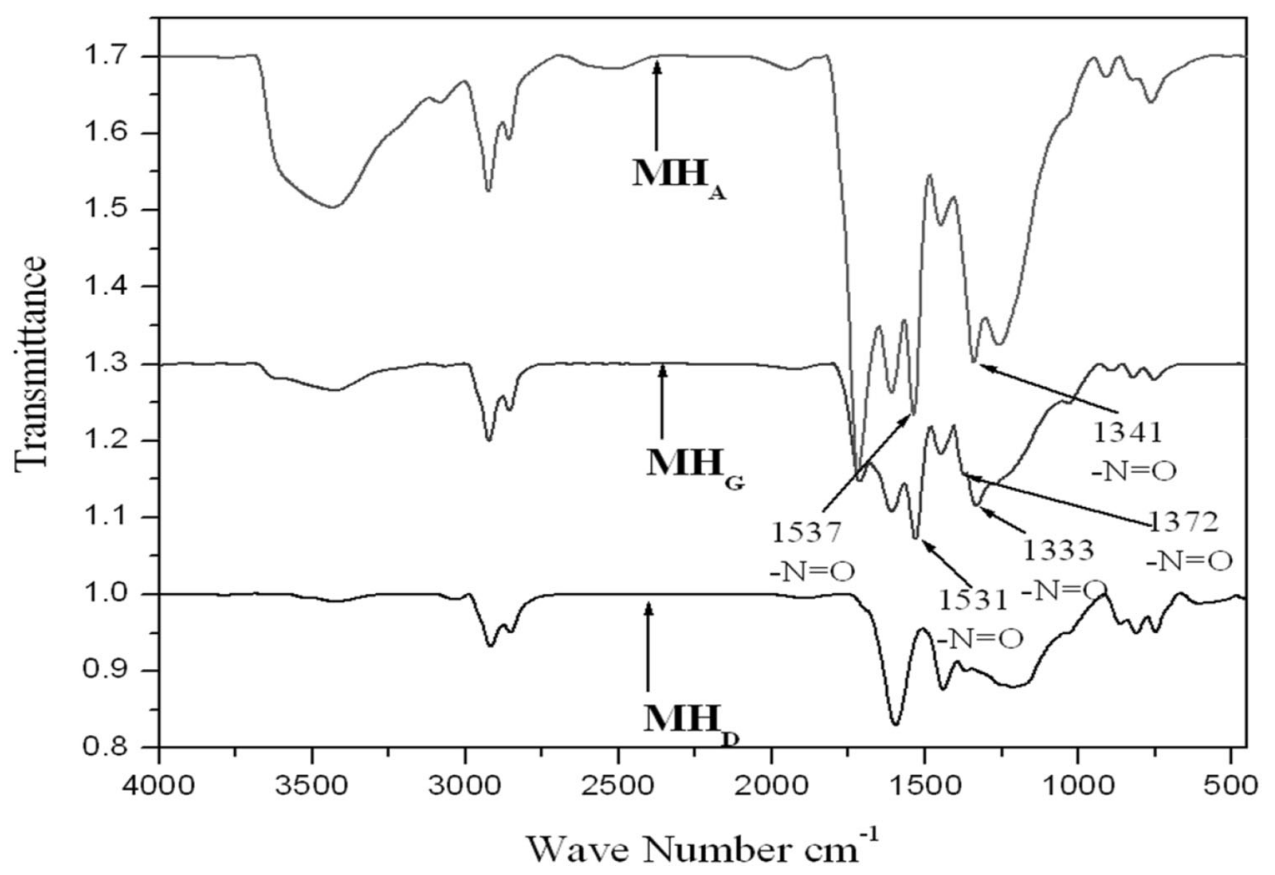

Fig. 8 FTIR curves of Mohuda (MH) coal

be observed that $N_{\mathrm{c}}$ have increased with increase in $\mathrm{C}_{\mathrm{dmf}}$ content (Table 2). Similar kind of relationship between $N_{\mathrm{c}}$ and $\mathrm{C}_{\mathrm{dmf}}$ has also been observed for demineralized pyrolyzed coals (Takagi et al. 2004; Wu and Zhang 2019) as observed in the present work. Also, the $N_{\mathrm{c}}$ values are the highest for demineralized samples followed by the corresponding nitric acid treated coals in aqueous medium and then to glacial acetic acid medium. This suggests that in treated coals, the structure of the coals is disordered due to nitration which reduces the average aromatic layers of SMCs. The degree of disorder is more in the case of glacial acetic acid treated coals than in aqueous medium.

The results of intensity ratio of $\pi$ - and $\gamma$ - band $\left(I_{26} / I_{20}\right)$ are also known as X-ray rank parameter and for demineralized and treated coals in both the media are shown in Table 4. The variation of $I_{26} / I_{20}$ values of raw as well as treated coals are plotted against $\mathrm{C}_{\mathrm{dmf}}$ content and shown in Fig. 7. The nature of curves is similar for raw as well as treated coals in both the nitration media. A very good linear fit of the curves are observed having $R^{2}=0.9963$ for demineralized coal (Fig. 7a). The nitric acid treated coals show linear increase of approx. $R^{2}=0.96$ in glacial acetic acid medium and aqueous medium respectively (Fig. 7b, c). Thus, the chemical $\left(\mathrm{C}_{\mathrm{dmf}}\right)$ and $\mathrm{X}$-ray $\left(I_{26} / I_{20}\right)$ rank parameters agree with each other to express the maturity of coal. Inter-layer spacing of $\gamma$-band $\left(D_{\gamma}\right)$ occurs around $20^{\circ}$ and is believed to be derived from aliphatic side chains of coal molecules. The $D \gamma$ values obtained for demineralized and SMCs formed do not show any trend in the present study (Table 4).

\subsection{Fourier transform infrared spectroscopy (FTIR)}

The broad strong stretching band of -OH (hydroxyl) group is shown in the range of $3600-3200 \mathrm{~cm}^{-1}$ produced mainly due to moisture in coal. In some of the samples stretch band of alkene $\left(=\mathrm{CH}_{2}\right)$ of small to medium intensity of $\left(3100-3010 \mathrm{~cm}^{-1}\right)$ are observed. The $2950-2800 \mathrm{~cm}^{-1}$ appeared as sharp peak of medium intensity and are assigned to aliphatic and alicyclic $-\mathrm{CH}_{3},-\mathrm{CH}_{2}$ and $-\mathrm{CH}$ groups; though the major contributor is the $-\mathrm{CH}_{2}$ groups. The peaks $\sim 1700 \mathrm{~cm}^{-1}$ has appeared due to strong stretching band of carbonyl/ketone $(\mathrm{C}=\mathrm{O})$ group. The bending vibration of alkane $\left(-\mathrm{CH}_{3}\right)$ appears in the range of $1470-1350 \mathrm{~cm}^{-1}$. The peaks $\sim 1600 \mathrm{~cm}^{-1}$ are observed due to medium to stretching bands of $\mathrm{C}=\mathrm{C}$ aromatic compounds. Ester and/or ether groups are formed at $1320-1210 \mathrm{~cm}^{-1}$. The region between 900 and $700 \mathrm{~cm}^{-1}$ is assigned to various bands related to aromatic, out-ofplane $\mathrm{C}-\mathrm{H}$ bending, $-\mathrm{OH}$ group with different degree of substitution.

In the samples of nitric acid treated coals, both in glacial acetic acid medium and aqueous medium, a distinct stretch asymmetric strong band of nitro $\left(-\mathrm{NO}_{2}\right)$ groups of aromatic compound appears in the range of $1550-1490 \mathrm{~cm}^{-1}$. A$\mathrm{CH}_{3}$ bending band and $-\mathrm{CH}_{2}$ group in bridges of variable intensity has been observed in the range of $1430-1290 \mathrm{~cm}^{-1}$. It has also been observed that strong stretch symmetrical nitro $\left(\mathrm{NO}_{2}\right)$ group appears in the range of $1355-1315 \mathrm{~cm}^{-1}$ in nitric acid treated coals in both the media. Covalent nitro-groups $\left(\mathrm{Ar}-\mathrm{O}-\mathrm{NO}_{2}\right)$ are formed at 
1255-1300 $\mathrm{cm}^{-1}$. A strong stretch band of ether $(\mathrm{C}-\mathrm{O})$ appeared in $1300-1000 \mathrm{~cm}^{-1}$. A deformation bending arene bond of nitro-groups is absent in the range of $860-840 \mathrm{~cm}^{-1}$.

The FTIR curves of demineralized coals, nitration in glacial acetic medium and nitration in aqueous medium are suffixed by D, G and A respectively and shown in Figs. 8, $9,10,11$. The areas of functional groups for all the demineralized as well as nitric acid treated coals in both nonaqueous and aqueous medium have been calculated by Gaussian probability density function using Origin 6.1 software and shown in Tables 5-8. In order to quantify the replacement of aliphatic side chains by nitro groups an attempt has been made to measure the area under peaks of aliphatic and alicyclic $(-\mathrm{CH})$ functional group of vibration (2950-2800 $\mathrm{cm}^{-1}$ ) and bending vibration of alkane $(-\mathrm{CH}$; $1470-1350 \mathrm{~cm}^{-1}$ ) are added for demineralized (raw) coals and corresponding nitric acid treated coals in both the media. The decrease in total areas of alkane group of raw and treated coals suggests the replacement of aliphatic side chains by nitro group. Total area of $-\mathrm{CH}_{3}$ group is decreased from $13.73 \mathrm{~cm}^{2}$ at $2917,2853 \mathrm{~cm}^{-1}$ and at $1441 \mathrm{~cm}^{-1}$ for demineralized coal to $10.76 \mathrm{~cm}^{2}$ at 2922 , 2856 and at $1449 \mathrm{~cm}^{-1}$ for $\mathrm{MH}_{\mathrm{G}}$ coal (Table 5). Total area decreased to $13.62 \mathrm{~cm}^{2}$ of $-\mathrm{CH}_{3}$ group in $\mathrm{MH}_{\mathrm{A}}$ at 2924, $2853 \mathrm{~cm}^{-1}$ and at $1450 \mathrm{~cm}^{-1}$ coal (Table 5).

Likewise, total area of $33.91 \mathrm{~cm}^{2}$ of $-\mathrm{CH}_{3}$ group in raw coal at $2917,2856 \mathrm{~cm}^{-1}$ and at $1439 \mathrm{~cm}^{-1}$ is decreased to $21.47 \mathrm{~cm}^{2}$ at $2923,2856 \mathrm{~cm}^{-1}$ and at $1452 \mathrm{~cm}^{-1}$ in $\mathrm{GT}_{\mathrm{G}}$ coal (Table 6) and total area of $\mathrm{CH}_{3}$ group is decreased to $13.59 \mathrm{~cm}^{2}$ at $2923,2859 \mathrm{~cm}^{-1}$ and at $1447 \mathrm{~cm}^{-1}$ for SMC in aqueous medium (Table 6).

Total areas of $-\mathrm{CH}_{3}$ group in demineralized coal at $\left(2917 \mathrm{~cm}^{-1}, 2854 \mathrm{~cm}^{-1}\right.$ and at $1439 \mathrm{~cm}^{-1}$ ) is $13.91 \mathrm{~cm}^{2}$ decreased to $13.05 \mathrm{~cm}^{2}$ in $\mathrm{SL}_{\mathrm{G}}\left(2921 \mathrm{~cm}^{-1}, 2855 \mathrm{~cm}^{-1}\right.$ and at $1446 \mathrm{~cm}^{-1}$; Table 7) and area of $\mathrm{CH}_{3}$ group is decreased to $7.54 \mathrm{~cm}^{2}$ at $2922 \mathrm{~cm}^{-1}, 2856 \mathrm{~cm}^{-1}$ and at $1449 \mathrm{~cm}^{-1}$ in $\mathrm{SL}_{\mathrm{A}}$ coal (Table 7).

Total areas of $\mathrm{CH}_{3}$ group in demineralized coal at $\left(2918 \mathrm{~cm}^{-1}, 2854 \mathrm{~cm}^{-1}\right.$ and at $\left.1440 \mathrm{~cm}^{-1}\right)$ is $20.56 \mathrm{~cm}^{2}$ decreased to $20.13 \mathrm{~cm}^{2}$ in $\mathrm{ST}_{\mathrm{G}}\left(2922 \mathrm{~cm}^{-1}, 2856 \mathrm{~cm}^{-1}\right.$ and at $1452 \mathrm{~cm}^{-1}$; Table 8) and total area of $-\mathrm{CH}_{3}$ group decreased to $19.99 \mathrm{~cm}^{2}$ in $\mathrm{ST}_{\mathrm{A}}$ at $2922 \mathrm{~cm}^{-1}, 2857 \mathrm{~cm}^{-1}$ and at $1447 \mathrm{~cm}^{-1}$ (Table 8).

This is a very significant finding that the decrease in total areas of alkane groups of demineralized and treated coals suggests the replacement of aliphatic side chains by nitro group.

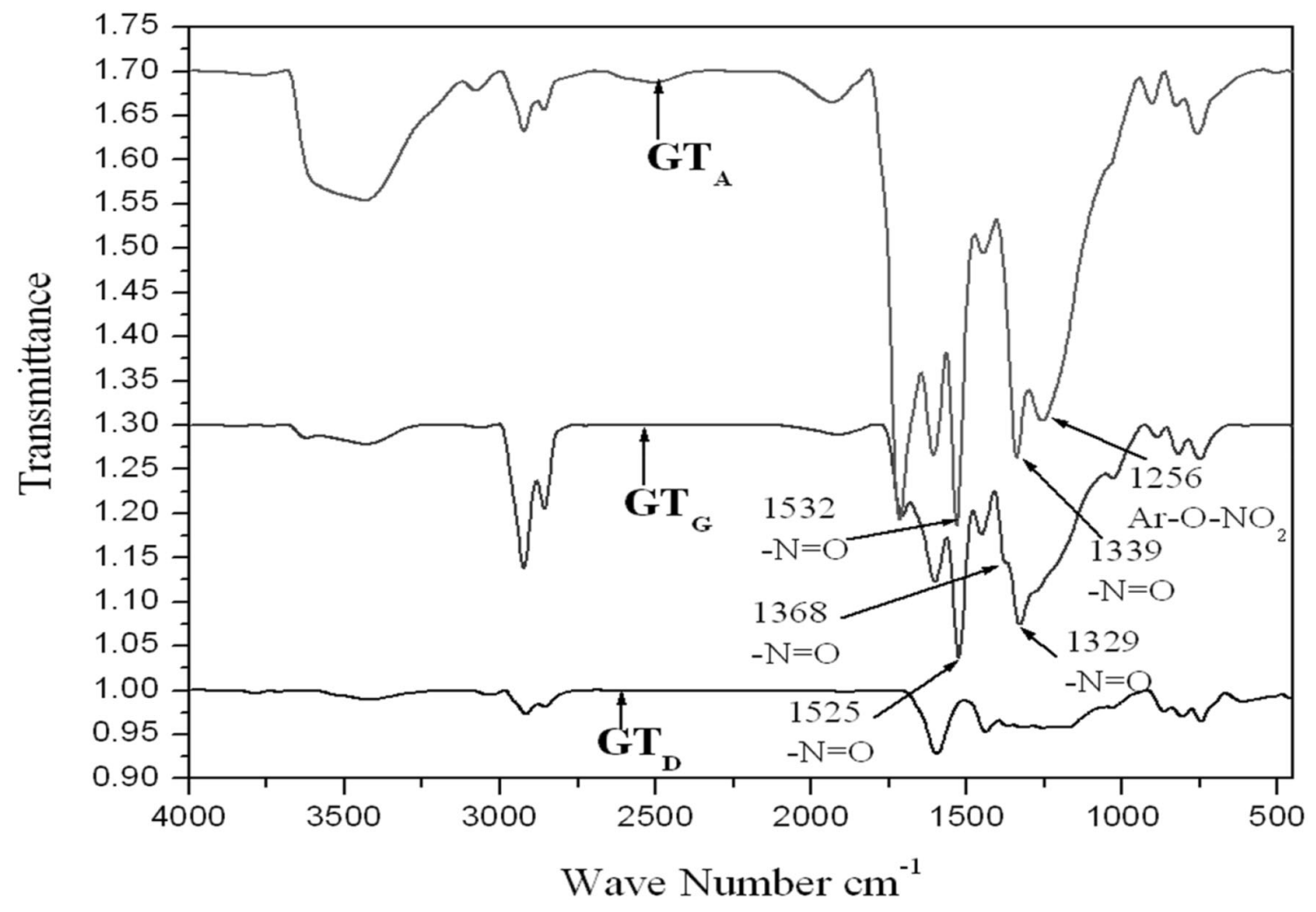

Fig. 9 FTIR curves of Gasalitand (GT) coal 


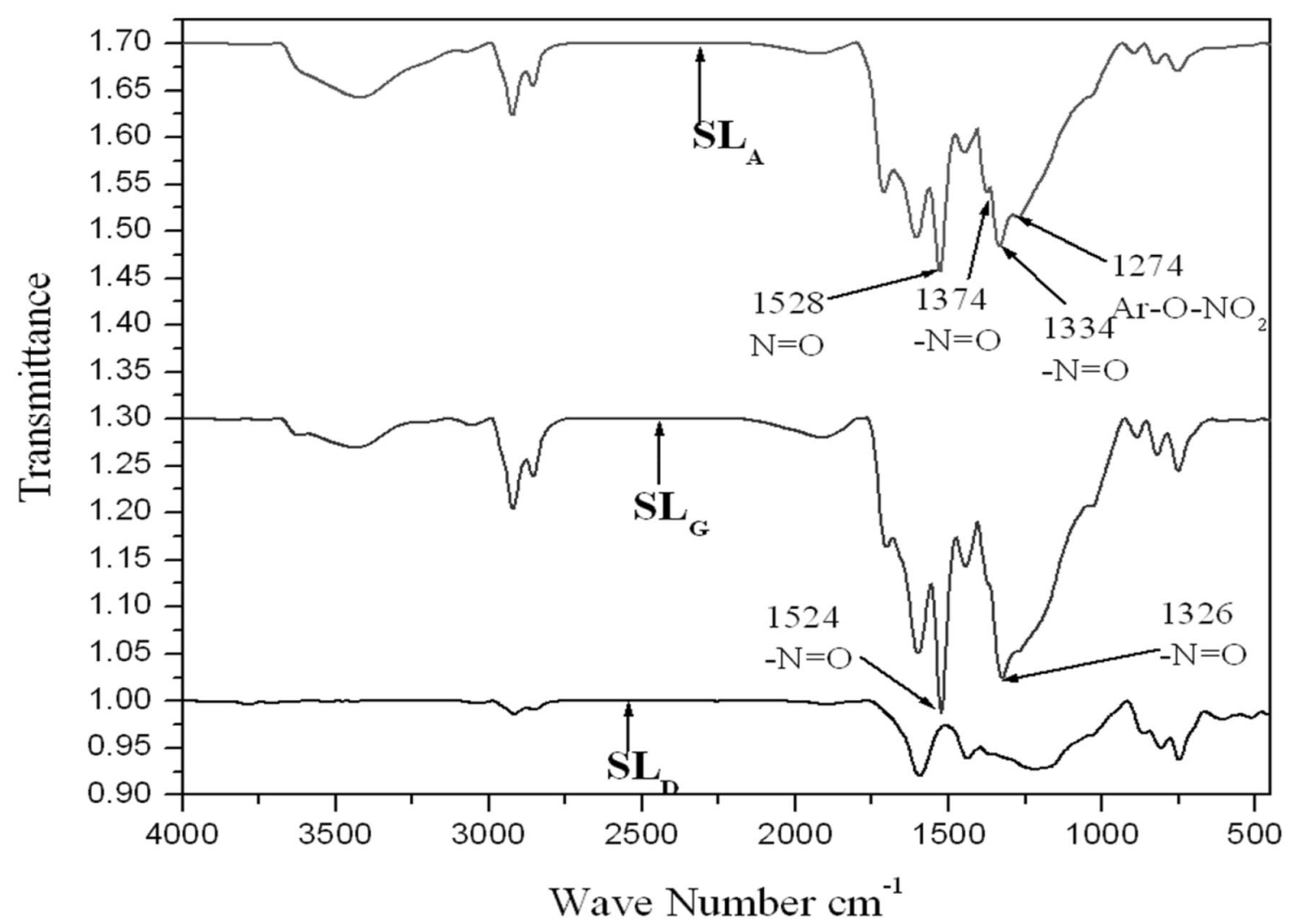

Fig. 10 FTIR curves of Salanpur (SL) coal

\section{Conclusions}

The variation of molecular structure of selected coals of Jharia Basin of Indian and their modifications through nitric acid treatment in acetic acid and aqueous media shows that the changes in the structural parameters and the aromaticity of the treated coals are dependent upon coal rank and the medium of treatment. Nitration has increased weight of SMCs in non-aqueous medium for all the coals under the present study. Whereas, the nitration in aqueous medium shows loss in weight for Mohuda (MH) coal and gain in weight for higher rank coals. Nitration in aqueous medium occurs simultaneous with oxidation of the coal matrix which removes more aliphatic side chains in the coal moieties, resulting relative increase in weight than that of non-aqueous medium. Significant observation in the present study is that nitration in both the media is capable of removing the aliphatic side chains for the coals and aromaticity increases with increase in rank (vitrinite reflectance) of coal.

FTIR studies show that coal arenes of the raw coals are converted into nitro-arenes in SMCs, the corresponding ands at $1550-1490$ and $1355-1315 \mathrm{~cm}^{-1}$ respectively. In the case of low rank coals, glacial acetic acid medium being milder medium might have resulted in the formation of covalent nitro groups $\left(\mathrm{Ar}-\mathrm{O}-\mathrm{NO}_{2}\right)$ in the range $1300-1255 \mathrm{~cm}^{-1}$ which is absent in relatively stronger aqueous medium where oxidation is also active phenomenon. FTIR study of nitric acid coals treated in both the media show introduction of nitrogen $(-\mathrm{N})$ and oxygen $(-\mathrm{O})$ containing groups and newly formed aromatic nucleus different from the raw coals which confirms the formation of structurally modified coals (SMCs). The areas under each functional group for demineralized samples and their corresponding SMCs have been calculated. The results show that the content of alkane group is decreased in SMCs corresponding to aliphatic and alicyclic $(-\mathrm{CH})$ functional group of vibration $\left(2950-2800 \mathrm{~cm}^{-1}\right)$ and bending vibration of alkane $\left(-\mathrm{CH} ; 1470-1350 \mathrm{~cm}^{-1}\right)$. The decrease in total areas of alkane group in treated coals than that of raw coals suggests the replacement of aliphatic side chains by nitro group.

The present study also reveals that in the SMCs of coals namely GT, SL and ST shows a considerable increase in aromaticity in aqueous medium and these are candidate coals for manufacturing of specialty carbon materials such as fullerene, artificial graphite, activated carbon and artificial diamond.

The major finding of this exhaustive study is highlighted below: 


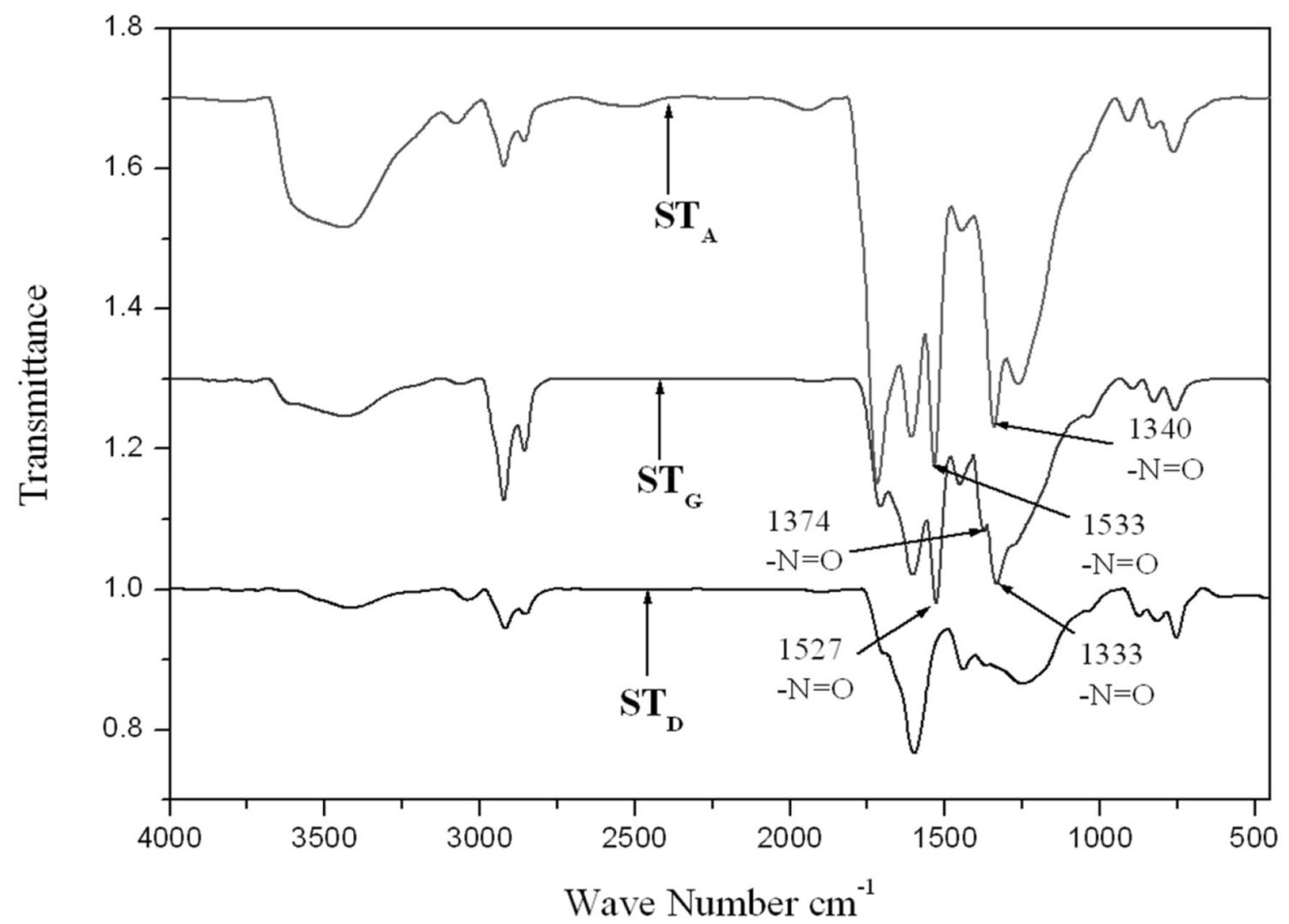

Fig. 11 FTIR curves of Shatabdi (ST) coal

(1) Nitration has increased weight of SMCs in nonaqueous medium for all the coals whereas the nitration in aqueous medium shows loss in weight for low rank coal $(\mathrm{MH})$ and gain in weight for higher rank coals.

(2) Nitration in aqueous medium occurs simultaneous with oxidation of the coal matrix which removes more aliphatic side chains in the coal moieties, resulting relative decrease in weight than that of non-aqueous medium.

(3) During nitration, loss of aliphatic side chains is more in aqueous medium than that of glacial acetic acid medium results to the relative increase of aromatic moieties in aqueous medium.

(4) The XRD structural parameters like mean crystallite size $\left(L_{\mathrm{c}}\right)$ and average number of aromatic layers $\left(N_{\mathrm{c}}\right)$ of corresponding SMCs have decreased in comparison to parent coals which indicate reorganization of spatial framework in SMC and disordering of crystallites.

(5) Nitration in stronger aqueous medium has resulted into increase in XRD rank $\left(I_{26} I_{20}\right)$ than raw coals.
(6) X-ray structural parameters are more dependent on coal rank and the content of macerals than only $\mathrm{C}_{\mathrm{dmf}}$.

(7) FTIR studies show that coal arenes of the raw coals are converted into nitro-arenes in SMCs, the corresponding bands at $1550-1490$ and $1355-1315 \mathrm{~cm}^{-1}$ respectively.

(8) In the case of low rank coals, glacial acetic acid medium being milder medium might have resulted in the formation of covalent nitro groups (Ar-O$\mathrm{NO}_{2}$ ) in the range $1300-1255 \mathrm{~cm}^{-1}$ which is absent in relatively stronger aqueous medium where oxidation is active phenomenon.

(9) FTIR study of nitric acid coals treated in both the media show introduction of nitrogen $(-\mathrm{N})$ and oxygen $(-\mathrm{O})$ containing groups and newly formed aromatic nucleus different from the raw coals which confirms the formation of structurally modified coals (SMCs).

(10) The decrease in total areas of alkane group of treated coals in comparison to raw coals suggests the replacement of aliphatic side chains by nitro group and hence area of $-\mathrm{CH}_{3}$ group is decreased. 
Table 5 FTIR analysis of Mohuda (MH) coal

\begin{tabular}{|c|c|c|c|c|c|}
\hline \multicolumn{6}{|l|}{$\mathrm{MH}_{\mathrm{D}}$} \\
\hline Wave number $\left(\mathrm{cm}^{-1}\right)$ & Functional group & & Type of vibration & Intensity & Area $\left(\mathrm{cm}^{2}\right)$ \\
\hline 3420 & $\mathrm{O}-\mathrm{H}$ & Phenolic/Hydroxyl & Stretch, H-bonded & Strong, broad & 1.54 \\
\hline 3043 & $=\mathrm{C}-\mathrm{H}$ & Alkene & Stretch & Strong & 0.86 \\
\hline 2917 & $\mathrm{C}-\mathrm{H}$ & Alkane & Stretch, symmetric & Strong & 4.00 \\
\hline 2853 & $\mathrm{C}-\mathrm{H}$ & Alkane & Stretch, asymmetric & Strong & 3.01 \\
\hline 1897 & $=\mathrm{C}-\mathrm{H}$ & Alkene & Stretch, asymmetric & Strong & 0.48 \\
\hline 1595 & $\mathrm{C}=\mathrm{C}$ & Arom./Arene & Scissoring & Med & 16.66 \\
\hline 1441 & $-\mathrm{C}-\mathrm{H}$ & Alkane & Bending & Variable & 6.72 \\
\hline 1368 & $\mathrm{~N}=\mathrm{O}$ & Nitro & Stretch, symmetric & Strong & 1.19 \\
\hline 1215 & $\mathrm{C}-\mathrm{O}$ & Ether/Ester & Stretch & Strong & 41.00 \\
\hline 863 & $=\mathrm{C}-\mathrm{H} / \mathrm{C}=\mathrm{C} / \mathrm{N}-\mathrm{H}$ & Alkene/Arene/Amine & Bending & Strong & 1.42 \\
\hline 811 & $=\mathrm{C}-\mathrm{H} / \mathrm{C}=\mathrm{C} / \mathrm{N}-\mathrm{H}$ & Alkene/Arene/Amine & Bending & Strong & 2.46 \\
\hline 749 & $\mathrm{O}-\mathrm{H} / \mathrm{C}=\mathrm{C} / \mathrm{N}-\mathrm{H}$ & Alcohol/Arene/Amine & Bending, out-of-plane & Weak & 2.91 \\
\hline \multicolumn{6}{|l|}{$\mathrm{MH}_{\mathrm{G}}$} \\
\hline Wave number $\left(\mathrm{cm}^{-1}\right)$ & Functional group & & Type of vibration & Intensity & Area $\left(\mathrm{cm}^{2}\right)$ \\
\hline 3423 & $\mathrm{O}-\mathrm{H}$ & Phenolic/Hydroxyl & Stretch, H-bonded & Strong, broad & 16.46 \\
\hline 3069 & $=\mathrm{C}-\mathrm{H}$ & Alkene & Stretch & Strong & 0.44 \\
\hline 2922 & $\mathrm{C}-\mathrm{H}$ & Alkane & Stretch, symmetric & Strong & 6.03 \\
\hline 2856 & $\mathrm{C}-\mathrm{H}$ & Alkane & Stretch, asymmetric & Strong & 2.72 \\
\hline 1926 & $=\mathrm{C}-\mathrm{H}$ & Alkene & Stretch, asymmetric & Strong & 0.82 \\
\hline 1713 & $\mathrm{C}=\mathrm{O}$ & Carbonyl/Ketone & Stretch & Strong & 9.27 \\
\hline 1608 & $\mathrm{C}=\mathrm{C}$ & Arom./Arene & Scissoring & Med & 19.78 \\
\hline 1531 & $\mathrm{~N}=\mathrm{O}$ & Nitro Arene & Stretch, asymmetric & Strong & 5.73 \\
\hline 1449 & $-\mathrm{C}-\mathrm{H}$ & Alkane & Bending & Variable & 2.01 \\
\hline 1372 & $\mathrm{~N}=\mathrm{O}$ & Nitro Arene & Stretch, symmetric & Strong & 5.78 \\
\hline 1333 & $\mathrm{~N}=\mathrm{O}$ & Nitro Arene & Stretch, symmetric & Strong & 65.14 \\
\hline 1032 & $\mathrm{C}-\mathrm{O}$ & Ether/Ester & Stretch & Strong & 2.56 \\
\hline 892 & $=\mathrm{C}-\mathrm{H} / \mathrm{C}=\mathrm{C} / \mathrm{N}-\mathrm{H}$ & Alkene/Arene/Amine & Bending & Strong & 0.06 \\
\hline 822 & $=\mathrm{C}-\mathrm{H} / \mathrm{C}=\mathrm{C} / \mathrm{N}-\mathrm{H}$ & Alkene/Arene/Amine & Bending & Strong & 0.54 \\
\hline 753 & $\mathrm{O}-\mathrm{H} / \mathrm{C}=\mathrm{C} / \mathrm{N}-\mathrm{H}$ & Alcohol/Arene/Amine & Bending, out-of-plane & Weak & 1.11 \\
\hline \multicolumn{6}{|l|}{$\mathrm{MH}_{\mathrm{A}}$} \\
\hline Wave number $\left(\mathrm{cm}^{-1}\right)$ & Functional group & & Type of vibration & Intensity & Area $\left(\mathrm{cm}^{2}\right)$ \\
\hline 3435 & $\mathrm{O}-\mathrm{H}$ & Phenolic/Hydroxyl & Stretch, H-bonded & Strong, broad & 34.42 \\
\hline 3084 & $=\mathrm{C}-\mathrm{H}$ & Alkene & Stretch & Strong & 6.88 \\
\hline 2924 & $\mathrm{C}-\mathrm{H}$ & Alkane & Stretch, symmetric & Strong & 8.82 \\
\hline 2858 & $\mathrm{C}-\mathrm{H}$ & Alkane & Stretch, asymmetric & Strong & 3.77 \\
\hline 2517 & $\mathrm{O}-\mathrm{H}$ & Carb. Acid & Stretch/Broad & Strong & 3.63 \\
\hline 1943 & $=\mathrm{C}-\mathrm{H}$ & Alkene & Stretch, asymmetric & Strong & 1.89 \\
\hline 1718 & $\mathrm{C}=\mathrm{O}$ & Carbonyl/Ketone & Stretch & Strong & 45.95 \\
\hline 1610 & $\mathrm{C}=\mathrm{C}$ & Arom./Arene & Scissoring & Med & 43.94 \\
\hline 1537 & $\mathrm{~N}=\mathrm{O}$ & Nitro Arene & Stretch, asymmetric & Strong & 14.74 \\
\hline 1450 & $-\mathrm{C}-\mathrm{H}$ & Alkane & Bending & Variable & 1.02 \\
\hline 1341 & $\mathrm{~N}=\mathrm{O}$ & Nitro Arene & Stretch, symmetric & Strong & 1.17 \\
\hline 1260 & $\mathrm{C}-\mathrm{O} / \mathrm{Ar}-\mathrm{O}-\mathrm{NO}_{2}$ & Ether/Ester/Covalent Nitrate & Stretch & Med-Weak & 122.15 \\
\hline 909 & $=\mathrm{C}-\mathrm{H}$ & Alkene & Bending & Strong & 0.72 \\
\hline 763 & $\mathrm{O}-\mathrm{H} / \mathrm{C}=/ \mathrm{N}-\mathrm{H}$ & Alcohol/Arene/Amine & Bending, out-of-plane & Weak & 6.63 \\
\hline
\end{tabular}


Table 6 FTIR analysis of Gasalitand (GT) coal

\begin{tabular}{|c|c|c|c|c|c|}
\hline \multicolumn{6}{|l|}{$\mathrm{GT}_{\mathrm{D}}$} \\
\hline Wave number $\left(\mathrm{cm}^{-1}\right)$ & Functional group & & Type of vibration & Intensity & Area $\left(\mathrm{cm}^{2}\right)$ \\
\hline 3414 & $\mathrm{O}-\mathrm{H}$ & Phenolic/Hydroxyl & Stretch, H-bonded & Strong, broad & 2.18 \\
\hline 3033 & $=\mathrm{C}-\mathrm{H}$ & Alkene & Stretch & Strong & 0.32 \\
\hline 2917 & $\mathrm{C}-\mathrm{H}$ & Alkane & Stretch, symmetric & Strong & 11.63 \\
\hline 2856 & $\mathrm{C}-\mathrm{H}$ & Alkane & Stretch, asymmetric & Strong & 8.17 \\
\hline 1596 & $\mathrm{C}=\mathrm{C}$ & Arom./Arene & Scissoring & Med & 5.43 \\
\hline 1439 & $-\mathrm{C}-\mathrm{H}$ & Alkane & Bending & Variable & 14.11 \\
\hline 1368 & $\mathrm{~N}=\mathrm{O} / \mathrm{C}-\mathrm{H}$ & Nitro/Alkane & Stretch, symmetric & Strong/variable & 0.82 \\
\hline 1320 & $\mathrm{C}-\mathrm{N}$ & Amine & Stretch & Strong & 0.92 \\
\hline 1032 & $\mathrm{C}-\mathrm{O}$ & Ether/Ester & Stretch & Strong & 0.72 \\
\hline 866 & $=\mathrm{C}-\mathrm{H} / \mathrm{C}=\mathrm{C} / \mathrm{N}-\mathrm{H}$ & Alkene/Arene/Amine & Bending & Strong & 0.92 \\
\hline 808 & $=\mathrm{C}-\mathrm{H} / \mathrm{C}=\mathrm{C} / \mathrm{N}-\mathrm{H}$ & Alkene/Arene/Amine & Bending & Strong & 1.36 \\
\hline 748 & $\mathrm{O}-\mathrm{H} / \mathrm{C}=\mathrm{C} / \mathrm{N}-\mathrm{H}$ & Alcohol/Arene/Amine & Bending, out-of-plane & Weak & 1.99 \\
\hline \multicolumn{6}{|l|}{$\mathrm{GT}_{\mathrm{G}}$} \\
\hline Wave number $\left(\mathrm{cm}^{-1}\right)$ & Functional group & & Type of vibration & Intensity & Area $\left(\mathrm{cm}^{2}\right)$ \\
\hline 3432 & $\mathrm{O}-\mathrm{H}$ & Phenolic/Hydroxyl & Stretch, H-bonded & Strong, broad & 5.81 \\
\hline 3065 & $=\mathrm{C}-\mathrm{H}$ & Alkene & Stretch & Strong & 0.44 \\
\hline 2923 & $\mathrm{C}-\mathrm{H}$ & Alkane & Stretch, symmetric & Strong & 10.34 \\
\hline 2856 & $\mathrm{C}-\mathrm{H}$ & Alkane & Stretch, asymmetric & Strong & 3.61 \\
\hline 1913 & $\mathrm{C}=\mathrm{C}$ & Arom./Arene & Stretch & Strong & 1.45 \\
\hline 1707 & $\mathrm{C}=\mathrm{O}$ & Carbonyl/Ketone & Stretch & Strong & 5.54 \\
\hline 1602 & $\mathrm{C}=\mathrm{C}$ & Arom./Arene & Scissoring & Med & 13.39 \\
\hline 1525 & $\mathrm{~N}=\mathrm{O}$ & Nitro Arene & Stretch, asymmetric & Strong & 9.24 \\
\hline 1452 & $-\mathrm{C}-\mathrm{H}$ & Alkane & Bending & Variable & 7.52 \\
\hline 1329 & $\mathrm{~N}=\mathrm{O}$ & Nitro Arene & Stretch, symmetric & Strong & 14.35 \\
\hline 1030 & $\mathrm{C}-\mathrm{O}$ & Ether/Ester & Stretch & Strong & 9.34 \\
\hline 888 & $=\mathrm{C}-\mathrm{H} / \mathrm{C}=\mathrm{C} / \mathrm{N}-\mathrm{H}$ & Alkene/Arene/Amine & Bending & Strong & 0.64 \\
\hline 820 & $=\mathrm{C}-\mathrm{H} / \mathrm{C}=\mathrm{C} / \mathrm{N}-\mathrm{H}$ & Alkene/Arene/Amine & Bending & Strong & 1.22 \\
\hline 751 & $\mathrm{O}-\mathrm{H} / \mathrm{C}=\mathrm{C} / \mathrm{N}-\mathrm{H}$ & Alcohol/Arene/Amine & Bending, out-of-plane & Weak & 2.43 \\
\hline \multicolumn{6}{|l|}{$\mathrm{GT}_{\mathrm{A}}$} \\
\hline Wave number $\left(\mathrm{cm}^{-1}\right)$ & Functional group & & Type of vibration & Intensity & Area $\left(\mathrm{cm}^{2}\right)$ \\
\hline 3437 & $\mathrm{O}-\mathrm{H}$ & Phenolic/Hydroxyl & Stretch, H-bonded & Strong, broad & 55.15 \\
\hline 3077 & $=\mathrm{C}-\mathrm{H}$ & Alkene & Stretch & Strong & 1.24 \\
\hline 2923 & $\mathrm{C}-\mathrm{H}$ & Alkane & Stretch, symmetric & Strong & 4.50 \\
\hline 2859 & $\mathrm{C}-\mathrm{H}$ & Alkane & Stretch, asymmetric & Strong & 2.27 \\
\hline 2506 & $\mathrm{O}-\mathrm{H}$ & Carb. Acid & Stretch/Broad & Strong & 2.29 \\
\hline 1934 & $\mathrm{C}=\mathrm{C}$ & Arom./Arene & Stretch & Strong & 6.03 \\
\hline 1715 & $\mathrm{C}=\mathrm{O}$ & Carbonyl/Ketone & Stretch & Strong & 39.29 \\
\hline 1606 & $\mathrm{C}=\mathrm{C}$ & Arom./Arene & Scissoring & Med & 48.28 \\
\hline 1532 & $\mathrm{~N}=\mathrm{O}$ & Nitro Arene & Stretch, asymme & Strong & 14.19 \\
\hline 1447 & $-\mathrm{C}-\mathrm{H}$ & Alkane & Bending & Variable & 6.83 \\
\hline 1339 & $\mathrm{~N}=\mathrm{O}$ & Nitro Arene & Stretch, symmetric & Strong & 4.06 \\
\hline 1256 & $\mathrm{C}-\mathrm{O} / \mathrm{Ar}-\mathrm{O}-\mathrm{NO}_{2}$ & Ether/Ester/Covalent Nitrate & Stretch & Med-Weak & 122.29 \\
\hline 905 & $=\mathrm{C}-\mathrm{H}$ & Alkene & Bending & Strong & 0.94 \\
\hline 826 & $=\mathrm{C}-\mathrm{H} / \mathrm{C}=\mathrm{C} / \mathrm{N}-\mathrm{H}$ & Alkene/Arene/Amine & Bending & Strong & 0.77 \\
\hline 759 & $\mathrm{O}-\mathrm{H} / \mathrm{C}=\mathrm{C} / \mathrm{N}-\mathrm{H}$ & Alcohol/Arene/Amine & Bending, out-of-plane & Weak & 7.73 \\
\hline
\end{tabular}


Table 7 FTIR analysis of Salanpur (SL) coal

\begin{tabular}{|c|c|c|c|c|c|}
\hline \multicolumn{6}{|l|}{$\mathrm{SL}_{\mathrm{D}}$} \\
\hline Wave number $\left(\mathrm{cm}^{-1}\right)$ & Functional group & & Type of vibration & Intensity & Area $\left(\mathrm{cm}^{2}\right)$ \\
\hline 3440 & $\mathrm{O}-\mathrm{H}$ & Phenolic/Hydroxyl & Stretch, H-bonded & Strong, broad & 0.12 \\
\hline 3043 & $=\mathrm{C}-\mathrm{H}$ & Alkene & Stretch & Strong & 0.66 \\
\hline 2917 & $\mathrm{C}-\mathrm{H}$ & Alkane & Stretch, symmetric & Strong & 0.94 \\
\hline 2854 & $\mathrm{C}-\mathrm{H}$ & Alkane & Stretch, asymmetric & Strong & 0.49 \\
\hline 1897 & $\mathrm{C}=\mathrm{C}$ & Arom./Arene & Stretch & Strong & 0.45 \\
\hline 1594 & $\mathrm{C}=\mathrm{C}$ & Arom./Arene & Scissoring & Med & 7.95 \\
\hline 1439 & $-\mathrm{C}-\mathrm{H}$ & Alkane & Bending & Variable & 12.48 \\
\hline 1220 & $\mathrm{C}-\mathrm{O}$ & Ether/Ester & Stretch & Strong & 27.44 \\
\hline 865 & $=\mathrm{C}-\mathrm{H} / \mathrm{C}=\mathrm{C} / \mathrm{N}-\mathrm{H}$ & Alkene/Arene/Amine & Bending & Strong & 1.19 \\
\hline 807 & $=\mathrm{C}-\mathrm{H} / \mathrm{C}=\mathrm{C} / \mathrm{N}-\mathrm{H}$ & Alkene/Arene/Amine & Bending & Strong & 2.00 \\
\hline 748 & $\mathrm{O}-\mathrm{H} / \mathrm{C}=\mathrm{C} / \mathrm{N}-\mathrm{H}$ & Alcohol/Arene/Amine & Bending, out-of-plane & Weak & 3.65 \\
\hline \multicolumn{6}{|l|}{$\mathrm{SL}_{\mathrm{G}}$} \\
\hline Wave number $\left(\mathrm{cm}^{-1}\right)$ & Functional group & & Type of vibration & Intensity & Area $\left(\mathrm{cm}^{2}\right)$ \\
\hline 3435 & $\mathrm{O}-\mathrm{H}$ & Phenolic/Hydroxyl & Stretch, H-bonded & Strong, broad & 7.79 \\
\hline 3058 & $=\mathrm{C}-\mathrm{H}$ & Alkene & Stretch & Strong & 1.22 \\
\hline 2921 & $\mathrm{C}-\mathrm{H}$ & Alkane & Stretch, symmetric & Strong & 5.61 \\
\hline 2855 & $\mathrm{C}-\mathrm{H}$ & Alkane & Stretch, asymmetric & Strong & 2.83 \\
\hline 1916 & $\mathrm{C}=\mathrm{C}$ & Arom./Arene & Stretch & Strong & 3.78 \\
\hline 1703 & $\mathrm{C}=\mathrm{O}$ & Carbonyl/Ketone & Stretch & Strong & 8.71 \\
\hline 1599 & $\mathrm{C}=\mathrm{C}$ & Arom./Arene & Scissoring & Med & 23.07 \\
\hline 1524 & $\mathrm{~N}=\mathrm{O}$ & Nitro Arene & Stretch, asymmetric & Strong & 10.30 \\
\hline 1446 & $-\mathrm{C}-\mathrm{H}$ & Alkane & Bending & Variable & 4.61 \\
\hline 1326 & $\mathrm{~N}=\mathrm{O}$ & Nitro Arene & Stretch, symmetric & Strong & 88.03 \\
\hline 886 & $=\mathrm{C}-\mathrm{H} / \mathrm{C}=\mathrm{C} / \mathrm{N}-\mathrm{H}$ & Alkene/Arene/Amine & Bending & Strong & 0.36 \\
\hline 820 & $=\mathrm{C}-\mathrm{H} / \mathrm{C}=\mathrm{C} / \mathrm{N}-\mathrm{H}$ & Alkene/Arene/Amine & Bending & Strong & 1.30 \\
\hline 751 & $\mathrm{O}-\mathrm{H} / \mathrm{C}=\mathrm{C} / \mathrm{N}-\mathrm{H}$ & Alcohol/Arene/Amine & Bending, out-of-plane & Weak & 3.06 \\
\hline \multicolumn{6}{|l|}{$\mathrm{SL}_{\mathrm{A}}$} \\
\hline Wave number $\left(\mathrm{cm}^{-1}\right)$ & Functional group & & Type of vibration & Intensity & Area $\left(\mathrm{cm}^{2}\right)$ \\
\hline 3422 & $\mathrm{O}-\mathrm{H}$ & Phenolic/Hydroxyl & Stretch, H-bonded & Strong, broad & 20.66 \\
\hline 2922 & $\mathrm{C}-\mathrm{H}$ & Alkane & Stretch, symmetric & Strong & 4.53 \\
\hline 2856 & $\mathrm{C}-\mathrm{H}$ & Alkane & Stretch, asymmetric & Strong & 1.94 \\
\hline 1930 & $\mathrm{C}=\mathrm{C}$ & Arom./Arene & Stretch & Strong & 2.21 \\
\hline 1711 & $\mathrm{C}=\mathrm{O}$ & Carbonyl/Ketone & Stretch & Strong & 9.68 \\
\hline 1605 & $\mathrm{C}=\mathrm{C}$ & Arom./Arene & Scissoring & Med & 22.15 \\
\hline 1528 & $\mathrm{~N}=\mathrm{O}$ & Nitro Arene & Stretch, asymmetric & Strong & 7.05 \\
\hline 1449 & $-\mathrm{C}-\mathrm{H}$ & Alkane & Bending & Variable & 1.08 \\
\hline 1374 & $\mathrm{~N}=\mathrm{O}$ & Nitro Arene & Stretch, symmetric & Strong & 0.64 \\
\hline 1334 & $\mathrm{~N}=\mathrm{O}$ & Nitro Arene & Stretch, symmetric & Strong & 2.56 \\
\hline 1274 & $\mathrm{C}-\mathrm{O} / \mathrm{Ar}-\mathrm{O}-\mathrm{NO}_{2}$ & Ether/Ester/Covalent Nitrate & Stretch & Med-Weak & 65.66 \\
\hline 895 & $=\mathrm{C}-\mathrm{H} / \mathrm{C}=\mathrm{C} / \mathrm{N}-\mathrm{H}$ & Alkene/Arene/Amine & Bending & Strong & 0.14 \\
\hline 825 & $=\mathrm{C}-\mathrm{H} / \mathrm{C}=\mathrm{C} / \mathrm{N}-\mathrm{H}$ & Alkene/Arene/Amine & Bending & Strong & 0.59 \\
\hline 754 & $\mathrm{O}-\mathrm{H} / \mathrm{C}=\mathrm{C} / \mathrm{N}-\mathrm{H}$ & Alcohol/Arene/Amine & Bending, out-of-plane & Weak & 2.29 \\
\hline
\end{tabular}


Table 8 FTIR analysis of Shatabdi (ST) coal

\begin{tabular}{|c|c|c|c|c|c|}
\hline \multicolumn{6}{|l|}{$\mathrm{ST}_{\mathrm{D}}$} \\
\hline Wave number $\left(\mathrm{cm}^{-1}\right)$ & Functional group & & Type of vibration & Intensity & Area $\left(\mathrm{cm}^{2}\right)$ \\
\hline 3414 & $\mathrm{O}-\mathrm{H}$ & Phenolic/Hydroxyl & Stretch, H-bonded & Strong, broad & 5.76 \\
\hline 3042 & $=\mathrm{C}-\mathrm{H}$ & Alkene & Stretch & Strong & 0.95 \\
\hline 2918 & $\mathrm{C}-\mathrm{H}$ & Alkane & Stretch, symmetric & Strong & 4.33 \\
\hline 2854 & $\mathrm{C}-\mathrm{H}$ & Alkane & Stretch, asymmetric & Strong & 1.82 \\
\hline 1901 & $\mathrm{C}=\mathrm{C}$ & Arom./Arene & Stretch & Strong & 0.47 \\
\hline 1599 & $\mathrm{C}=\mathrm{C}$ & Arom./Arene & Scissoring & Med & 31.25 \\
\hline 1440 & $-\mathrm{C}-\mathrm{H}$ & Alkane & Bending & Variable & 14.41 \\
\hline 1253 & $\mathrm{C}-\mathrm{O}$ & Ether/Ester & Stretch & Strong & 35.60 \\
\hline 874 & $=\mathrm{C}-\mathrm{H} / \mathrm{C}=\mathrm{C} / \mathrm{N}-\mathrm{H}$ & Alkene/Arene/Amine & Bending & Strong & 1.62 \\
\hline 815 & $=\mathrm{C}-\mathrm{H} / \mathrm{C}=\mathrm{C} / \mathrm{N}-\mathrm{H}$ & Alkene/Arene/Amine & Bending & Strong & 2.48 \\
\hline 753 & $\mathrm{O}-\mathrm{H} / \mathrm{C}=\mathrm{C} / \mathrm{N}-\mathrm{H}$ & Alcohol/Arene/Amine & Bending, out-of-plane & Weak & 3.38 \\
\hline \multicolumn{6}{|l|}{$\mathrm{ST}_{\mathrm{G}}$} \\
\hline Wave number $\left(\mathrm{cm}^{-1}\right)$ & Functional group & & Type of vibration & Intensity & Area $\left(\mathrm{cm}^{2}\right)$ \\
\hline 3427 & $\mathrm{O}-\mathrm{H}$ & Phenolic/Hydroxyl & Stretch, H-bonded & Strong, broad & 17.30 \\
\hline 3064 & $=\mathrm{C}-\mathrm{H}$ & Alkene & Stretch & Strong & 0.48 \\
\hline 2922 & $\mathrm{C}-\mathrm{H}$ & Alkane & Stretch, symmetric & Strong & 9.57 \\
\hline 2856 & $\mathrm{C}-\mathrm{H}$ & Alkane & Stretch, asymmetric & Strong & 3.98 \\
\hline 1922 & $\mathrm{C}=\mathrm{C}$ & Arom./Arene & Stretch & Strong & 0.01 \\
\hline 1708 & $\mathrm{C}=\mathrm{O}$ & Carbonyl/Ketone & Stretch & Strong & 10.02 \\
\hline 1603 & $\mathrm{C}=\mathrm{C}$ & Arom./Arene & Scissoring & Med & 28.04 \\
\hline 1527 & $\mathrm{~N}=\mathrm{O}$ & Nitro Arene & Stretch, asymmetric & Strong & 8.76 \\
\hline 1452 & $-\mathrm{C}-\mathrm{H}$ & Alkane & Bending & Variable & 6.58 \\
\hline 1374 & $\mathrm{~N}=\mathrm{O}$ & Nitro Arene & Stretch, symmetric & Strong & 32.10 \\
\hline 1333 & $\mathrm{~N}=\mathrm{O}$ & Nitro Arene & Stretch, symmetric & Strong & 54.10 \\
\hline 894 & $=\mathrm{C}-\mathrm{H} / \mathrm{C}=\mathrm{C} / \mathrm{N}-\mathrm{H}$ & Alkene/Arene/Amine & Bending & Strong & 0.44 \\
\hline 826 & $=\mathrm{C}-\mathrm{H} / \mathrm{C}=\mathrm{C} / \mathrm{N}-\mathrm{H}$ & Alkene/Arene/Amine & Bending & Strong & 1.32 \\
\hline 757 & $\mathrm{O}-\mathrm{H} / \mathrm{C}=\mathrm{C} / \mathrm{N}-\mathrm{H}$ & Alcohol/Arene/Amine & Bending, out-of-plane & Weak & 1.96 \\
\hline \multicolumn{6}{|l|}{$\mathrm{ST}_{\mathrm{A}}$} \\
\hline Wave number $\left(\mathrm{cm}^{-1}\right)$ & Functional group & & Type of vibration & Intensity & Area $\left(\mathrm{cm}^{2}\right)$ \\
\hline 3440 & $\mathrm{O}-\mathrm{H}$ & Phenolic/Hydroxyl & Stretch, H-bonded & Strong, broad & 68.34 \\
\hline 3077 & $=\mathrm{C}-\mathrm{H}$ & Alkene & Stretch & Strong & 2.22 \\
\hline 2922 & $\mathrm{C}-\mathrm{H}$ & Alkane & Stretch, symmetric & Strong & 5.85 \\
\hline 2857 & $=\mathrm{C}-\mathrm{H}$ & Alkane & Stretch, asymmetric & Strong & 2.70 \\
\hline 2516 & $\mathrm{O}-\mathrm{H}$ & Carb. Acid & Stretch/Broad & Strong & 2.27 \\
\hline 1941 & $=\mathrm{C}-\mathrm{H}$ & Alkene & Stretch, asymmetric & Strong & 2.19 \\
\hline 1717 & $\mathrm{C}=\mathrm{O}$ & Carbonyl/Ketone & Stretch & Strong & 46.74 \\
\hline 1607 & $\mathrm{C}=\mathrm{C}$ & Arom./Arene & Scissoring & Med & 48.12 \\
\hline 1533 & $\mathrm{~N}=\mathrm{O}$ & Nitro Arene & Stretch, asymmetric & Strong & 11.75 \\
\hline 1447 & $-\mathrm{C}-\mathrm{H}$ & Alkane & Bending & Variable & 11.44 \\
\hline 1340 & $\mathrm{~N}=\mathrm{O}$ & Nitro Arene & Stretch, symmetric & Strong & 5.24 \\
\hline 1264 & $\mathrm{C}-\mathrm{O} / \mathrm{Ar}-\mathrm{O}-\mathrm{NO}_{2}$ & Ether/Ester/Covalent Nitrate & Stretch & Med-Weak & 113.27 \\
\hline 908 & $=\mathrm{C}-\mathrm{H}$ & Alkene & Bending & Strong & 2.12 \\
\hline 831 & $=\mathrm{C}-\mathrm{H} / \mathrm{C}=\mathrm{C} / \mathrm{N}-\mathrm{H}$ & Alkene/Arene/Amine & Bending & Strong & 2.34 \\
\hline 763 & $\mathrm{O}-\mathrm{H} / \mathrm{C}=\mathrm{C} / \mathrm{N}-\mathrm{H}$ & Alcohol/Arene/Amine & Bending, out-of-plane & Weak & 8.49 \\
\hline
\end{tabular}


Acknowledgements We thank the Director, CSIR-Central Institute of Mining and Fuel Research, Dhanbad for permission to publish this paper. We also thank our colleagues at the Resource Quality Assessment and CTL Research Group for their support.

Open Access This article is licensed under a Creative Commons Attribution 4.0 International License, which permits use, sharing, adaptation, distribution and reproduction in any medium or format, as long as you give appropriate credit to the original author(s) and the source, provide a link to the Creative Commons licence, and indicate if changes were made. The images or other third party material in this article are included in the article's Creative Commons licence, unless indicated otherwise in a credit line to the material. If material is not included in the article's Creative Commons licence and your intended use is not permitted by statutory regulation or exceeds the permitted use, you will need to obtain permission directly from the copyright holder. To view a copy of this licence, visit http://creativecommons. org/licenses/by/4.0/.

\section{References}

ASTM D5016 (2016) Standard test method for total sulfur in coal and coke combustion residues using a high-temperature tube furnace combustion method with infrared absorption

Alonso MJ, Borrego AG, Alvarez D, Parra JB, Menéndez R (2001) Influence of pyrolysis temperature on char optical texture and reactivity. J Anal Appl Pyrolysis 58:887-909. https://doi.org/10. 1016/S0165-2370(00)00186-8

ASTM D5373 (2016) Standard test methods for determination of carbon, hydrogen and nitrogen in analysis samples of coal and carbon in analysis samples of coal and coke

ASTM D5865 (2013) Standard test method for gross calorific value of coal and coke

Barbara K, Slawomira P, Brett JV, ICCP, (2019) Application of electron microscopy TEM and SEM for analysis of coals, organic rich shales and carbonaceous matter. Int J Coal Geol 211:1-13. https://doi.org/10.1016/j.coal.2019.05.010

Baysal M, Yürüm A, Yildiz B, Yürüm Y (2016) Structure of some western Anatolia coals investigated by FTIR, Raman, ${ }^{13} \mathrm{C}$ solid state NMR spectroscopy and X-ray diffraction. Int J Coal Geol 163:166-176. https://doi.org/10.1016/j.coal.2016.07.009

Boral P, Varma AK, Maity S (2015) X-ray diffraction studies of some structurally modified Indian coals and their correlation with petrographic parameters. Curr Sci 108(3):384-394

Borrego AG, Marbán G, Alonso MJG, Älvarez D, Menéndez R (2000) Maceral effects in the determination of proximate volatiles in coals. Energy Fuels 14:117-126. https://doi.org/10. 1021/ef990050t

Chandra D (1992) Jharia Coalfield. Geological Society of India, India

Dangyu S, Cunbei Y, Xiaokui Z, Xianbo S, Xiaodong Z (2011) Structure of the organic crystalline unit in coal as determined by X-ray diffraction. Min Sci Technol China 21:667-671. https:// doi.org/10.1016/j.mstc.2011.10.004

Domazetis G, James BD (2006) Molecular models of brown coal containing inorganic species. Org Geochem 37:244-259. https:// doi.org/10.1016/j.orggeochem.2005.07.006

Guerrero A, Diez MA, Borrego AG (2013) Effect of volatile matter release on optical properties of macerals from different rank coals. Fuel 114:21-30. https://doi.org/10.1016/j.fuel.2012.05. 023

Hirsch PB (1954) X-Ray scattering from coals. In: Proceedings of the Royal Society (London), A 226:143-169

IS 436 Part 1/Sec 1 (2001) Methods of sampling of coal and coke, part 1: sampling of coal, Section 1: manual sampling
IS 9127 Part 2 (2002) Methods for the petrographic analysis of bituminous coal and anthracite-part 2: method of preparing coal samples

IS 9127 Part 3 (2002) Methods for the petrographic analysis of bituminous coal and anthracite - Part 3: Method of determining maceral group composition

IS 9127 Part 5 (2004) Methods for the petrographic analysis of bituminous coal and anthracite - Part 5: Method of determining microscopically the reflectance of vitrinite

Jing Z, Rodrigues S, Strounina E, Li M, Wood B, Underschultz JR, Esterle JS, Steel KM (2019) Use of FTIR, XPS, NMR to characterize oxidative effects of $\mathrm{NaClO}$ on coal molecular structures. Int J Coal Geol 201:1-13. https://doi.org/10.1016/j. coal.2018.11.017

Krishnan MS (1982) Geology of India and Burma. Publishers and Distributors, India, C.B.S.

Li K, Khanna R, Zhang J, Barati M, Liu Z, Xu T, Yang T, Sahajwalla $\mathrm{V}$ (2015) Comprehensive investigation of structural features of bituminous coals using advanced analytical techniques. Energy Fuels 29:7178-7189. https://doi.org/10.1021/acs.energyfuels. $5 \mathrm{~b} 02064$

Lu L, Sahajwalla V, Kong C, Harris D (2001) Quantitative X-ray diffraction analysis and its application to various coals. Carbon 39:1821-1833. https://doi.org/10.1016/S0008-6223(00)00318-3

Maity S, Choudhury A (2008) Influence of nitric acid treatment in different media on X-ray structural parameters of coal. Energy Fuels 22:4087-4091. https://doi.org/10.1021/ef800424w

Maity S, Mukherjee P (2006) X-ray structural parameters of some Indian coals. Curr Sci 91:337-340

Manoj B, Kunjomana AG (2012) Study of stacking structure of amorphous carbon by X-ray diffraction technique. Int $\mathrm{J}$ Electrochem Sci 7:3127-3134

Mathews JP, Chaffee AL (2012) The molecular representations of coal—a review. Fuel 96:1-14. https://doi.org/10.1016/j.fuel. 2011.11.025

Painter PC, Coleman MM (1979) Application of Fourier-transform infrared spectroscopy to the characterization of fractionated coal liquids. Fuel 58:301-308. https://doi.org/10.1016/00162361(79)90141-8

Painter PC, Coleman MM, Jenkins RG, Walker PL Jr (1978) Fourier transform infrared study of acid-demineralized coal. Fuel 57:125-126. https://doi.org/10.1016/0016-2361(78)90113-8

Solomon PR, Serio MA, Carangelo RM, Bassilakis R, Gravel D, Baillargeon M, Baudais F, Vail G (1990) Analysis of the Argonne premium coal samples by thermogravimetric Fourier transform infrared spectroscopy. Energy Fuels 4:319-333. https://doi.org/10.1021/ef00021a017

Solum MS, Pugmire RJ, Grant DM (1989) Carbon-13 solid-state NMR of Argonne premium coals. Energy Fuels 3:187-193. https://doi.org/10.1021/ef00014a012

Sonibare OO, Haeger T, Foley SF (2010) Structural characterization of Nigerian coals by X-ray diffraction, Raman and FTIR spectroscopy. Energy 35:5347-5353. https://doi.org/10.1016/j. energy.2010.07.025

Takagi H, Maruyama K, Yoshizawa N, Yamada Y, Sato Y (2004) XRD analysis of carbon stacking structure in coal during heat treatment. Fuel 83:2427-2433. https://doi.org/10.1016/j.fuel. 2004.06.019

Tamarkina YV, Shendrik TG, Krzton A, Kucherenko VA (2002) Reactivity and structural modification of coals in $\mathrm{HNO}_{3}-\mathrm{Ac}_{2} \mathrm{O}$ system. Fuel Proc Tech 77-78:9-15. https://doi.org/10.1016/ S0378-3820(02)00059-0

Wertz DL (1998) X-ray scattering analysis of the average poly-cyclic aromatic unit in Argonne premium coal 401. Fuel 77:43-53. https://doi.org/10.1016/S0016-2361(97)00150-6 
Wertz DL, Bissell M (1994) Relating the non ideal diffraction from the graphene layer stacking peak to the aliphatic carbon abundance in bituminous coals. Energy Fuels 8:613-617. https://doi.org/10.1021/ef00045a016

Wertz DL, Bissell M (1995) One-dimensional description of the average polycyclic aromatic unit in Pocahontas No. 3 coal: an X-ray scattering study. Fuel 74:1431-1435. https://doi.org/10. 1016/0016-2361(95)00107-G

Wertz DL, Quin JL (2000) Wide angle X-ray scattering study of the layering in three of the Argonne premium coals. Fuel 79:1981-1989. https://doi.org/10.1016/S0016-236(00)00026-0
Wu D, Zhang W (2019) Evolution mechanism of macromolecular structure in coal during heat treatment: based on FTIR and XRD in situ analysis techniques. J Spectr 2019:1-18. https://doi.org/ 10.1155/2019/5037836

Yan J, Lei Z, Li Z, Wang Z, Ren S, Kang S, Wang X, Shui H (2020) Molecular structure characterization of low-medium rank coals via XRD solid state ${ }^{13} \mathrm{C}$ NMR and FTIR spectroscopy. Fuel 268:1-9. https://doi.org/10.1016/j.fuel.2020.117038 